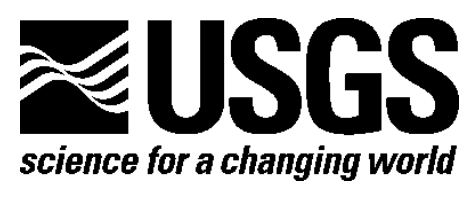

\title{
Evaluation of the Eureka Manta2 Water-Quality Multiprobe Sonde
}

By Evan F. Tillman

Open-File Report 2017-1118

U.S. Department of the Interior U.S. Geological Survey 


\section{U.S. Department of the Interior \\ RYAN K. ZINKE, Secretary}

\section{U.S. Geological Survey \\ William H. Werkheiser, Acting Director}

U.S. Geological Survey, Reston, Virginia: 2017

For more information on the USGS—-the Federal source for science about the Earth, its natural and living resources, natural hazards, and the environment-visit https://www.usgs.gov/ or call 1-888-ASK-USGS (1-888-275-8747).

For an overview of USGS information products, including maps, imagery, and publications, visit https://store.usgs.gov/.

Any use of trade, firm, or product names is for descriptive purposes only and does not imply endorsement by the U.S. Government.

Although this information product, for the most part, is in the public domain, it also may contain copyrighted materials as noted in the text. Permission to reproduce copyrighted items must be secured from the copyright owner.

Suggested citation:

Tillman, E.F., 2017, Evaluation of the Eureka Manta2 Water-Quality Multiprobe Sonde: U.S. Geological Survey Open-File Report 2017-1118, 37 p., https://doi.org/10.3133/ofr20171118.

ISSN 2331-1258 (online) 


\section{Contents}

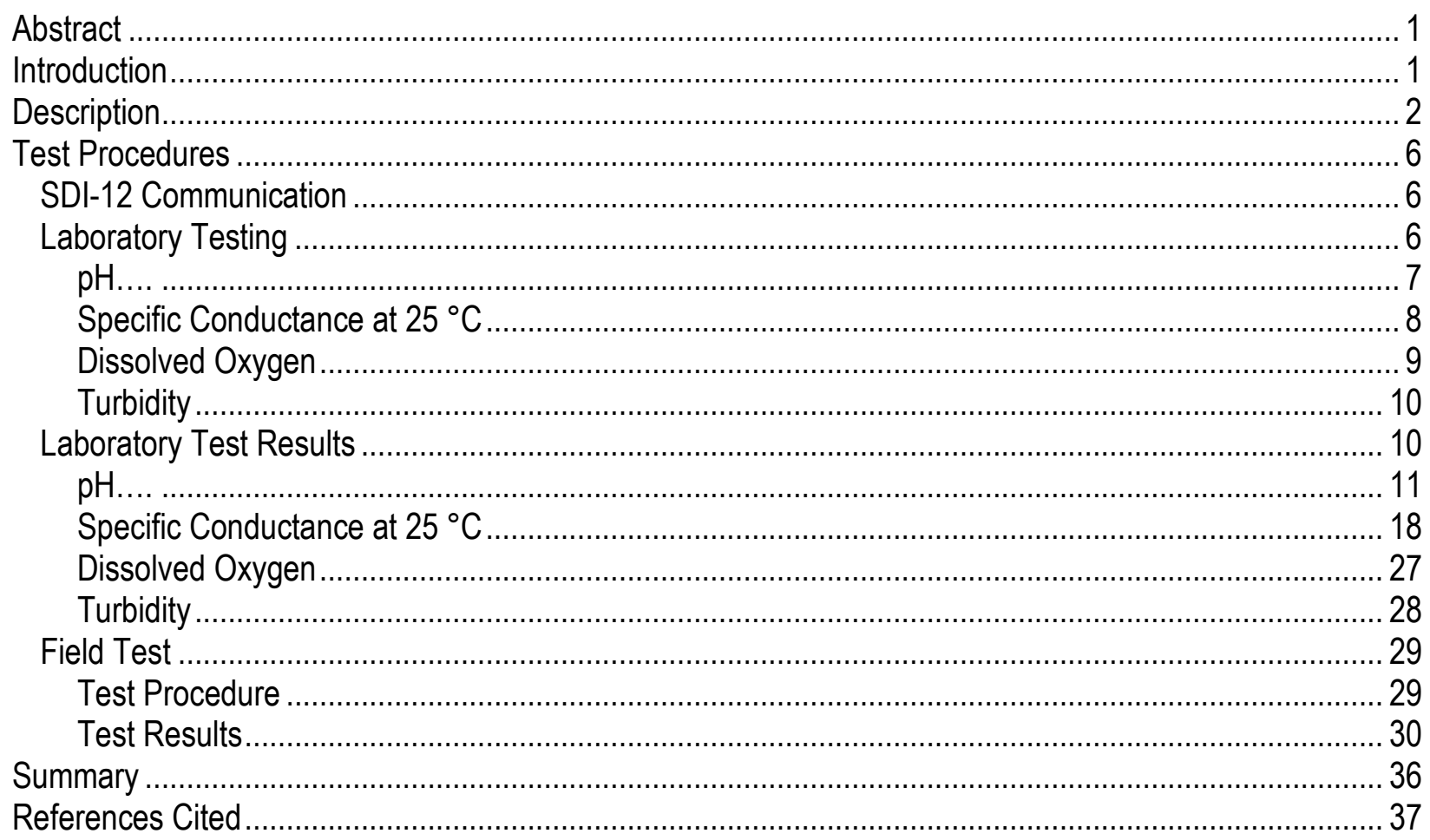

\section{Figures}

1. Photograph of the Eureka Manta2 3.5 water-quality multiprobe sonde and probe guard ................. 3

2. Photograph of the Eureka Manta2 3.5 water-quality multiprobe sonde as built for testing ................ 3

3. Photograph of the Eureka Manta2 water-quality multiprobe SDI-12 Converter device for interfacing with SDI-12 ................................................................................................. 4

4. Photograph of the Eureka Manta2 water-quality multiprobe 10-meter cable ………...................... 4

5. Graph showing difference in $\mathrm{pH}$ units between the Eureka Manta2 3.5 water-quality multiprobe sonde (serial number MT11131388) pH sensor calibrated at two $\mathrm{pH}$ ranges and $\mathrm{pH}$ standards at 5 degrees Celsius plotted with manufacturer and the U.S. Geological Survey "National Field Manual for the Collection of Water-Quality Data" accuracy limits

6. Graph showing difference in $\mathrm{pH}$ units between the Eureka Manta2 3.5 water-quality multiprobe sonde (serial number MT11131387) pH sensor calibrated at two pH ranges and $\mathrm{pH}$ standards at 5 degrees Celsius plotted with manufacturer and the U.S. Geological Survey "National Field Manual for the Collection of Water-Quality Data" accuracy limits

7. Graph showing difference in $\mathrm{pH}$ units between the Eureka Manta2 3.5 water-quality multiprobe sonde (serial number MT11131388) pH sensor calibrated at two $\mathrm{pH}$ ranges and $\mathrm{pH}$ standards at 15 degrees Celsius plotted with manufacturer and the U.S. Geological Survey "National Field Manual for the Collection of Water-Quality Data" accuracy limits.

8. Graph showing difference in $\mathrm{pH}$ units between the Eureka Manta2 3.5 water-quality multiprobe sonde (serial number MT11131387) pH sensor calibrated at two $\mathrm{pH}$ ranges and $\mathrm{pH}$ standards at 15 degrees Celsius plotted with manufacturer and the U.S. Geological Survey "National Field Manual for the Collection of Water-Quality Data" accuracy limits. 
9. Graph showing difference in $\mathrm{pH}$ units between the Eureka Manta2 3.5 water-quality multiprobe sonde (serial number MT11131388) pH sensor calibrated at two $\mathrm{pH}$ ranges and pH standards at 25 degrees Celsius plotted with manufacturer and the U.S. Geological Survey "National Field Manual for the Collection of Water-Quality Data" accuracy limits.

10. Graph showing difference in $\mathrm{pH}$ units between the Eureka Manta2 3.5 water-quality multiprobe sonde (serial number MT11131387) pH sensor calibrated at two $\mathrm{pH}$ ranges and pH standards at 25 degrees Celsius plotted with manufacturer and the U.S. Geological Survey "National Field Manual for the Collection of Water-Quality Data" accuracy limits 16

11. Graph showing difference in $\mathrm{pH}$ units between the Eureka Manta2 3.5 water-quality multiprobe sonde (serial number MT11131388) pH sensor calibrated at two pH ranges and $\mathrm{pH}$ standards at 40 degrees Celsius plotted with manufacturer and the U.S. Geological Survey "National Field Manual for the Collection of Water-Quality Data" accuracy limits

12. Graph showing difference in $\mathrm{pH}$ units between the Eureka Manta2 3.5 water-quality multiprobe sonde (serial number MT11131387) pH sensor calibrated at two pH ranges and $\mathrm{pH}$ standards at 40 degrees Celsius plotted with manufacturer and the U.S. Geological Survey" National Field Manual for the Collection of Water-Quality Data" accuracy limits

13. Graph showing percent difference between the Eureka Manta2 3.5 water-quality multiprobe sonde (serial number MT11131388) and the specific conductance standard measured at 5 degrees Celsius.

14. Graph showing percent difference between the Eureka Manta2 3.5 water-quality multiprobe sonde (serial number MT11131387) and the specific conductance standard measured at 5 degrees Celsius

15. Graph showing average percent difference between the Eureka Manta2 3.5 water-quality multiprobe sonde (serial number MT11131388) and the specific conductance standard measured at 15 degrees Celsius

16. Graph showing average percent difference between the Eureka Manta2 3.5 water-quality multiprobe sonde (serial number MT11131387) and the specific conductance standard measured at 15 degrees Celsius

17. Graph showing percent difference between the Eureka Manta2 3.5 water-quality multiprobe sonde (serial number MT11131388) and the specific conductance standard measured at 25 degrees Celsius.

18. Graph showing percent difference between the Eureka Manta2 3.5 water-quality multiprobe sonde (serial number MT11131387) and the specific conductance standard measured at 25 degrees Celsius.

19. Graph showing percent difference between the Eureka Manta2 3.5 water-quality multiprobe sonde (serial number MT11131388) and the specific conductance standard measured at 40 degrees Celsius.

20. Graph showing percent difference between the Eureka Manta2 3.5 water-quality multiprobe sonde (serial number MT11131387) and the specific conductance standard measured at 40 degrees Celsius

21. Graph showing difference in milligrams per liter between two Eureka Manta2 3.5 waterquality multiprobe sondes (serial numbers MT11131387 and MT11131388) and theoretical dissolved oxygen concentrations plotted with manufacturer and the U.S. Geological Survey "National Field Manual for the Collection of Water-Quality Data" accuracy limits .

22. Graph showing average percent differences between the Eureka Manta2 3.5 water-quality multiprobe sonde (serial number MT 11131388) turbidity sensor and ultrapure deionized water (0 nephelometric turbidity units [NTU] and StablCal turbidity standards of 10;20; 
40; 100; 400; 800; 1,000; 2,000; 2,500; and 3,000 NTU after a two-point calibration at 0 and 100 NTU

23. Graphs showing temperature differences between the Eureka Manta2 3.5 water-quality multiprobe test sonde with biweekly maintenance and the site sonde at U.S. Geological Survey (USGS) station 02492620 (Pearl River at National Space Technology Laboratories Station, Mississippi) over time (6 weeks), and temperature versus time for the site sonde and a YSI 6920 V2-2 Quality Control (QC) sonde ....

24. Graphs showing $\mathrm{pH}$ differences between the Eureka Manta2 3.5 water-quality multiprobe test sonde with biweekly maintenance and the site sonde at U.S. Geological Survey (USGS) station 02492620 (Pearl River at National Space Technology Laboratories Station, Mississippi) over time (6 weeks), and pH versus time for the site sonde and a YSI 6920 V2-2 Quality Control (QC) sonde

25. Graphs showing specific conductance differences between the Eureka Manta2 3.5 waterquality multiprobe test sonde with biweekly maintenance and the site sonde at U.S. Geological Survey (USGS) station (02492620 Pearl River at National Space Technology Laboratories Station, Mississippi) over time (6 weeks), and specific conductance versus time for the site sonde and a YSI 6920 V2-2 Quality Control (QC) sonde

26. Graphs showing dissolved oxygen differences between the Eureka Manta2 3.5 waterquality multiprobe test sonde with biweekly maintenance and the site sonde at U.S. Geological Survey (USGS) station 02492620 (Pearl River at National Space Technology Laboratories Station, Mississippi) over time (6 weeks), and dissolved oxygen versus time for the site sonde and a YSI 6920 V2-2 Quality Control (QC) sonde

\section{Tables}

1. The Eureka Manta2 3.5 water-quality multiprobe sonde's manufacturer specifications (Eureka Water Probes, 2015)

2. The pH standards used to test the $\mathrm{pH}$ sensor of the Eureka Manta2 3.5 water-quality multiprobe sonde and standard specifications at 25 degrees Celsius

3. Conductance standards used to test the conductance sensor of the Eureka Manta2 3.5 water-quality multiprobe sonde and standard specifications at 25 degrees Celsius .

Dissolved oxygen reference standards

5. Acceptance criteria for field test comparison of the Eureka Manta2 3.5 water-quality multiprobe sonde and the Hydrolab Data Sonde 5 site sonde.

6. Summary statistics for the test sonde, the Eureka Manta2 3.5 water-quality multiprobe test sonde (serviced biweekly), and the site sonde at U.S. Geological Survey station 02492620 Pearl River at National Space Technology Laboratories Station, Mississippi.

(Hydrolab Data Sonde 5 - serviced every week over a 6-week deployment.)

7. Fouling- and calibration-drift corrections for the Eureka Manta2 3.5 water-quality multiprobe test sonde after a 6-week deployment at U.S. Geological Survey station 02492620 Pearl River at National Space Technology Laboratories Station, Mississippi, with maintenance every 2 weeks. The sonde was calibrated on July 22, 2014. The correction values were not applied to the sonde data.

8. Accuracy ratings of continuous water-quality records, reprinted from U.S. Geological Survey Techniques and Methods 1-D3, table 18, 2006. 


\section{Conversion Factors}

International System of Units to U.S. customary units

\begin{tabular}{|c|c|c|}
\hline Multiply & By & To obtain \\
\hline \multicolumn{3}{|c|}{ Length } \\
\hline centimeter $(\mathrm{cm})$ & 0.3937 & inch (in.) \\
\hline meter $(\mathrm{m})$ & 3.281 & foot $(\mathrm{ft})$ \\
\hline \multicolumn{3}{|c|}{ Volume } \\
\hline liter $(\mathrm{L})$ & 33.81402 & ounce, fluid (fl. oz) \\
\hline liter $(\mathrm{L})$ & 2.113 & pint $(p t)$ \\
\hline liter $(\mathrm{L})$ & 1.057 & quart (qt) \\
\hline liter (L) & 0.2642 & gallon (gal) \\
\hline \multicolumn{3}{|c|}{ Pressure } \\
\hline kilopascal (kPa) & 0.009869 & atmosphere, standard (atm) \\
\hline kilopascal (kPa) & 0.01 & bar \\
\hline kilopascal (kPa) & 0.2961 & inch of mercury at $60^{\circ} \mathrm{F}$ (in $\mathrm{Hg}$ ) \\
\hline
\end{tabular}

Temperature in degrees Celsius $\left({ }^{\circ} \mathrm{C}\right)$ may be converted to degrees Fahrenheit $\left({ }^{\circ} \mathrm{F}\right)$ as ${ }^{\circ} \mathrm{F}=\left(1.8 \times{ }^{\circ} \mathrm{C}\right)+32$.

\section{Supplemental Information}

Specific conductance is given in microsiemens per centimeter at 25 degrees Celsius $\left(\mu \mathrm{S} / \mathrm{cm}\right.$ at $\left.25^{\circ} \mathrm{C}\right)$.

Concentrations of chemical constituents in water are given in milligrams per liter (mg/L). 


\title{
Evaluation of the Eureka Manta2 Water-Quality Multiprobe Sonde
}

\author{
By Evan F. Tillman
}

\begin{abstract}
Two Eureka Manta2 3.5 water-quality multiprobe sondes by Eureka Water Probes were tested at the U.S. Geological Survey (USGS) Hydrologic Instrumentation Facility (HIF) against known standards over the sonde operating temperatures to verify the manufacturer's stated accuracy specifications for $\mathrm{pH}$, specific conductance (SC) at 25 degrees Celsius $\left({ }^{\circ} \mathrm{C}\right)$, dissolved oxygen (DO), and turbidity. The Manta2 sondes were evaluated for compliance with the USGS National Field Manual for the Collection of Water-Quality Data (NFM) criteria for continuous water-quality monitors, and for compliance with the manufacturer's technical specifications. The Manta2 was also evaluated for its compliance to Serial Digital Interface at 1200 baud (SDI-12) version 1.3 .

The Manta2 met the NFM recommendations and manufacturer's accuracy specifications for DO and turbidity at all values tested. The Manta $2 \mathrm{pH}$ sensors met the NFM recommendations and manufacturer's accuracy specification for nominal $\mathrm{pH}$ values of 10 and lower. One of the two sensors was out of compliance by 1.2 units for $\mathrm{pH} 11.16$ at $15^{\circ} \mathrm{C}$ and by 0.25 unit for $\mathrm{pH}$ 10.78 at $40^{\circ} \mathrm{C}$. The Manta 2 sensors were within the NFM recommendations for SC, except at 100 microsiemens $(\mu \mathrm{S} / \mathrm{cm})$ at $40{ }^{\circ} \mathrm{C}$, where the SC sensor exceeded the test standard value by as much as 25 percent. One of two sensors was within manufacturer's accuracy specifications at 25 ${ }^{\circ} \mathrm{C}$ for all the tested SC values, while the other SC sensor was outside the manufacturer's accuracy specifications at $100 \mu \mathrm{S} / \mathrm{cm}$, exceeding the test standard value by 9 percent. One of two sensors was outside the manufacturer's accuracy specifications at $10,000 \mu \mathrm{S} / \mathrm{cm}$ at $15^{\circ} \mathrm{C}$, exceeding the test standard value by 3 percent. One Manta2 passed SDI-12 compliance testing with a NR Systems SDI-12 Verifier. One Manta2 was field tested for 6 weeks at USGS station 02492620, National Space Technology Laboratories (NSTL) Station, Mississippi, on the Pearl River and showed overall good agreement with a well-maintained Hydrolab Datasonde 5X site sonde for water temperature, $\mathrm{pH}$, and DO. Differences in SC values between the Manta2 and the site sonde were most likely due to differences in the deployment depth of the sondes.
\end{abstract}

\section{Introduction}

The U.S. Geological Survey (USGS) Hydrologic Instrumentation Facility (HIF) evaluates the performance of instruments and equipment that are used to measure hydrologic data. Evaluation reports document the results at the time of testing, and may or may not represent future instrument performance resulting from updates and improvements to the device. These reports are not an endorsement by the USGS, but rather a tool for use by USGS personnel to facilitate the decision-making process when selecting instruments and equipment for use in the 
field. This report documents the laboratory and field evaluation of the Manta2 3.5 water-quality multiprobe sonde (http://www.waterprobes.com) from Eureka Water Probes (previously owned by Measurement Specialties). After a brief description of the sonde model tested, the communication, laboratory, field test procedures, and all test results are described and discussed. All findings are based on testing of the Eureka Water Probes Manta 2.0 with control software version 2.0.165 and sensor firmware version 6.84.

\section{Description}

The Manta2 3.5 water-quality multiprobe sonde (Manta2; fig. 1) from Eureka Water Probes is custom built with the customer's choice of sensors ranging from a minimum of 2 (temperature and $\mathrm{pH}$ reference) to a maximum of 11 of the 23 available sensors. The model tested was built with temperature, $\mathrm{pH}$, conductance, dissolved oxygen (DO), and turbidity sensors (fig. 2). The Manta2 offers several communication protocols, including Bluetooth, Serial Data Interface at 1200 baud (SDI-12) (fig. 3), and the Electronic Industries Alliance's serial communication Recommended Standard-232 (RS-232), for use with an external controller/logger. The 3.5-inchdiameter version is equipped with internal power and logging capability. The sonde may be used for unattended monitoring and is designed for surface-water and groundwater applications. Sonde programming is accomplished using a computer running the Eureka Water Probes Manta 2.0 control software (version 2.0.165) and a RS-232 to Universal Serial Bus (USB) cable interface. The Manta2 uses Eureka cables (vented or unvented; fig. 4) for power and communication. Eureka cables are available in various lengths up to 656 feet (ft) (200 meters $[\mathrm{m}])$.

The $\mathrm{pH}$ sensor's reference electrode is refillable and has a replaceable Teflon junction. The Manta2 3.5 water-quality multiprobe sonde measures conductance and temperature, and uses Standard Methods 2510 B (Eaton and others, 2005) to correct the conductance sensor measurement to specific conductance (SC) at $25{ }^{\circ} \mathrm{C}$. All measurements of conductance are in specific conductance and throughout this report the sensor is referred to as a specific conductance sensor. The software in the Manta2 3.5 water-quality multiprobe sonde will also compute salinity and total dissolved solids from the SC sensor measurements. The DO sensor is a luminescence-based optical sensor. The DO sensor's cap has a life of 2 to 5 years and the membrane does not need to be hydrated to work correctly. The turbidity sensor is an International Organization for Standardization (ISO) 7027-compliant nephelometric sensor that measures turbidity at 880 nanometers $(\mathrm{nm})$. Features and technical specifications for the Manta2 sonde and sensors are listed in table 1 (Eureka Water Probes, 2015). The sensors are not labeled with lot or serial numbers. 


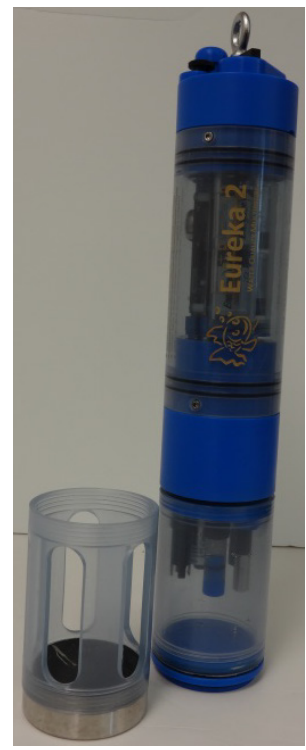

Figure 1. Photograph of the Eureka Manta2 3.5 water-quality multiprobe sonde and probe guard. Sonde equipped as tested with temperature, $\mathrm{pH}$, conductance, dissolved oxygen, and turbidity sensors.

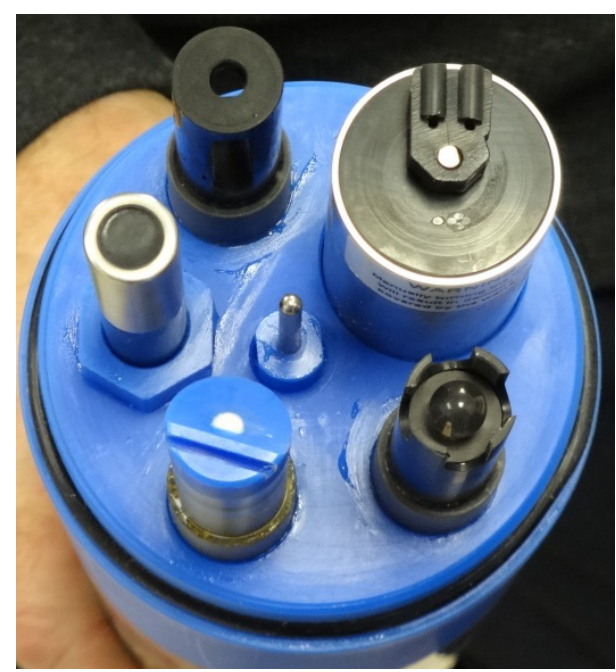

Figure 2. Photograph of the Eureka Manta2 3.5 water-quality multiprobe sonde as built for testing. From the top clockwise: conductance, turbidity, $\mathrm{pH}, \mathrm{pH}$ reference junction, and dissolved oxygen. Temperature sensor is in the center. 


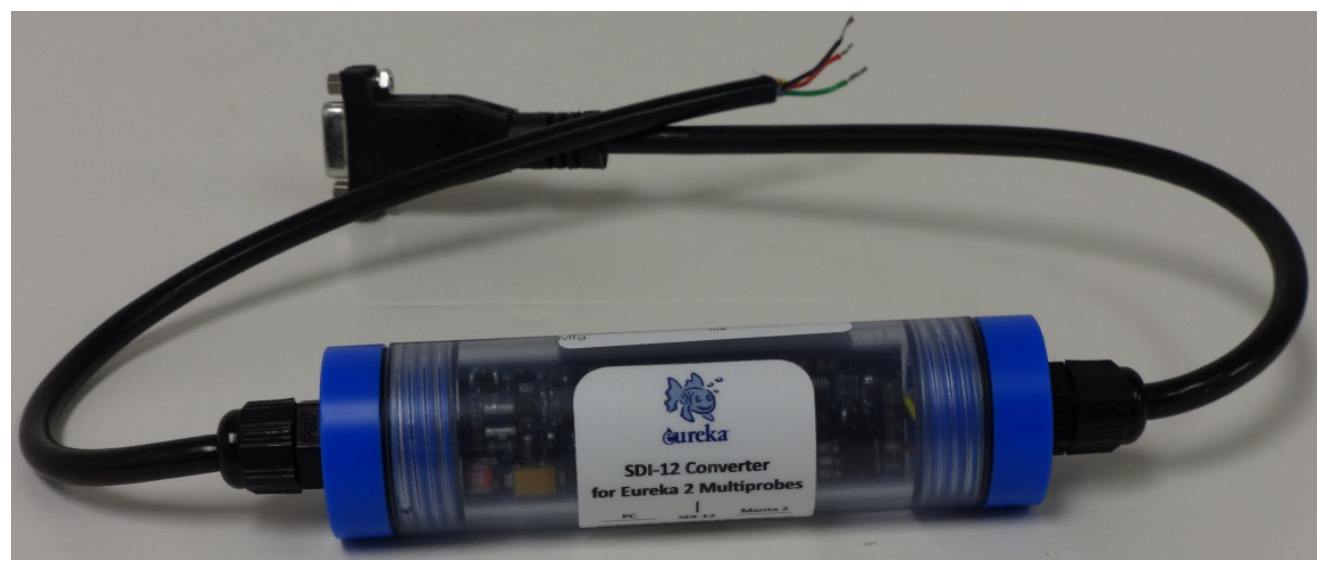

Figure 3. Photograph of the Eureka Manta2 water-quality multiprobe SDI-12 Converter device for interfacing with SDI-12.

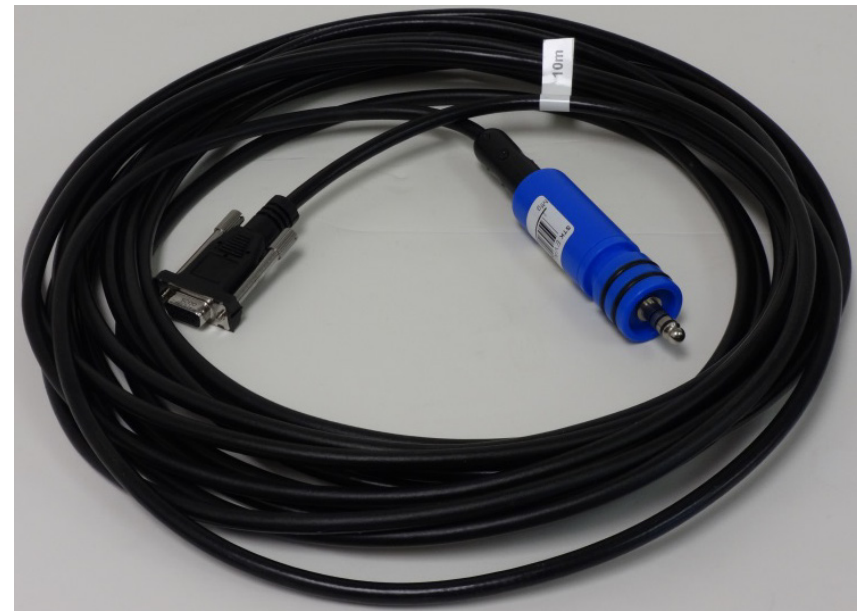

Figure 4. Photograph of the Eureka Manta2 water-quality multiprobe 10-meter cable. 
Table 1. The Eureka Manta2 3.5 water-quality multiprobe sonde's manufacturer specifications (Eureka Water Probes, 2015).

[PVC, polyvinyl chloride; in., inch; dia, diameter; cm, centimeter; kg, kilogram; lbs, pounds; VDC, volts direct current; m, meter; ft, feet; ${ }^{\circ} \mathrm{C}$, degree Celsius; ${ }^{\circ} \mathrm{F}$, degree Fahrenheit; SDI-12, Serial Data Interface at 1200 baud; $\mu \mathrm{S} / \mathrm{cm}$, microsiemens per centimeter; $\mathrm{mS} / \mathrm{cm}$, millisiemens per centimeter; $\%$, percent; $\mathrm{mg} / \mathrm{L}$, milligrams per liter; NTU, nephelometric turbidity units]

\begin{tabular}{|c|c|}
\hline Feature & Specification \\
\hline & General \\
\hline Housing material & PVC and DuPont ${ }^{\mathrm{TM}}$ Delrin ${ }^{\circledR}$ acetal homopolymer resin \\
\hline Dimensions & $8.89 \mathrm{~cm}$ (3.5 in.) dia $x 48.26 \mathrm{~cm}$ (19 in.) long \\
\hline Weight & $4.08-4.99 \mathrm{~kg}(9-11 \mathrm{lbs})$ \\
\hline \multicolumn{2}{|l|}{ Power } \\
\hline Internal & 6 "C" " alkaline cells \\
\hline External & $5-15 \mathrm{VDC}$ \\
\hline Maximum depth rating & $200 \mathrm{~m}(656 \mathrm{ft})$ \\
\hline Temperature operating range & $-5{ }^{\circ} \mathrm{C}$ to $50^{\circ} \mathrm{C}\left(23{ }^{\circ} \mathrm{F}\right.$ to $\left.122^{\circ} \mathrm{F}\right)$ \\
\hline Communication & Output: RS-232, SDI-12, or Bluetooth \\
\hline \multicolumn{2}{|c|}{ Specific conductance sensor ${ }^{1}$} \\
\hline Type & Four-cell conductance \\
\hline Units & $\mu \mathrm{S} / \mathrm{cm} ; \mathrm{mS} / \mathrm{cm}$ \\
\hline Range & $0 \mu \mathrm{S} / \mathrm{cm}$ to $100,000 \mu \mathrm{S} / \mathrm{cm}$ \\
\hline \multirow[t]{2}{*}{ Accuracy } & $\pm 1 \%+1 \mu \mathrm{S} / \mathrm{cm} @ 0$ to $1,000 \mu \mathrm{S} / \mathrm{cm}$ \\
\hline & $\pm 1 \% @ 1,000$ to $100,000 \mu \mathrm{S} / \mathrm{cm}$ \\
\hline \multirow[t]{2}{*}{ Resolution } & $0.1 \mu \mathrm{S} / \mathrm{cm} @ 0$ to $1,000 \mu \mathrm{S} / \mathrm{cm}$ \\
\hline & $1 \mu \mathrm{S} / \mathrm{cm} @ 1,000$ to $100,000 \mu \mathrm{S} / \mathrm{cm}$ \\
\hline \multicolumn{2}{|r|}{$\mathrm{pH}$ sensor } \\
\hline Type & $\begin{array}{l}\text { Glass sensing bulb, single-junction electrode, } \\
\text { replaceable Teflon junction, refillable reference } \\
\text { electrolyte }\end{array}$ \\
\hline Units & Standard $\mathrm{pH}$ units \\
\hline Range & 0 to $14 \mathrm{pH}$ units \\
\hline Accuracy & $\pm 0.2 \mathrm{pH}$ unit \\
\hline Resolution & $0.01 \mathrm{pH}$ unit \\
\hline \multicolumn{2}{|c|}{ Dissolved oxygen optical sensor } \\
\hline Type & Optical luminescence quenching \\
\hline Units & $\%$, percent saturation; $\mathrm{mg} / \mathrm{L}$ \\
\hline Range & 0 to $50 \mathrm{mg} / \mathrm{L}$ \\
\hline \multirow[t]{2}{*}{ Accuracy } & $\pm 0.2 \mathrm{mg} / \mathrm{L} @ 0-20 \mathrm{mg} / \mathrm{L}$ \\
\hline & $\pm 1 \%$ of reading@20-50 mg/L \\
\hline \multirow[t]{2}{*}{ Resolution } & $0.01 \mathrm{mg} / \mathrm{L}$ \\
\hline & Turbidity sensor \\
\hline Type & ISO 7027-compliant with wiper \\
\hline Units & NTU \\
\hline Range & 0 to $3,000 \mathrm{NTU}$ \\
\hline \multirow[t]{2}{*}{ Accuracy } & $\pm 1 \%$ reading+1NTU @ 0 to $400 \mathrm{NTU}$ \\
\hline & $\pm 3 \%$ reading@ 900 to 3,000 NTU \\
\hline
\end{tabular}

${ }^{1}$ Specific conductance readings are equivalent to conductance at $25^{\circ} \mathrm{C}$. 
Table 1. The Eureka Manta2 3.5 water-quality multiprobe sonde's manufacturer specifications (Eureka Water Probes, 2015).-Continued

\begin{tabular}{|c|c|}
\hline Feature & Specification \\
\hline Resolution & Four digits \\
\hline \multicolumn{2}{|r|}{ Temperature sensor } \\
\hline Type & Thermistor \\
\hline Units & ${ }^{\circ} \mathrm{C} ;{ }^{\circ} \mathrm{F}$ \\
\hline Range & $-5^{\circ} \mathrm{C}$ to $50^{\circ} \mathrm{C}\left(23^{\circ} \mathrm{F}\right.$ to $\left.122^{\circ} \mathrm{F}\right)$ \\
\hline Accuracy & $\pm 0.1^{\circ} \mathrm{C}$ \\
\hline Resolution & $0.01{ }^{\circ} \mathrm{C}$ \\
\hline \multicolumn{2}{|r|}{ Operating software } \\
\hline
\end{tabular}

Eureka Water Probes Manta 2.0 control software version 2.0.165

Eureka Water Probes Manta2 Firmware version 6.84

\section{Test Procedures}

Testing was conducted using two Eureka Manta 2 sondes (serial number MT11131388 and serial number MT11131387) equipped with temperature, $\mathrm{SC}, \mathrm{pH}, \mathrm{DO}$, and turbidity sensors. To evaluate compliance with the SDI-12 protocol, the Eureka SDI-12 adaptor for the Manta2 was tested using an industry standard verifier. To evaluate compliance with USGS accuracy requirements and the manufacturer's stated accuracy specifications for the $\mathrm{pH}, \mathrm{DO}, \mathrm{SC}$, and turbidity sensors, a Manta2 was tested against known standards in a controlled laboratory environment. To evaluate performance and calibration drift over time, a Manta2 from the laboratory test was field tested at the HIF's Pearl River testing site.

In this report, differences are computed as the device under test minus the reference value, or difference=Manta2-reference. For laboratory tests, the reference was the solution standard value and for the field deployment the permanently installed and maintained site sonde at USGS station 02492620, National Space Technology Laboratories (NSTL) Station, Mississippi, was the reference.

\section{SDI-12 Communication}

The Manta2 uses a SDI-12 adaptor (fig. 3) compliant with SDI-12 version 1.3 to communicate with SDI-12. The SDI-12 function was checked using an NR Systems SDI-12 Verifier (software version 5.0.0.24, Verifier firmware 1.6) and an adaptor installed on a test sonde. The verifier's "Comprehensive Sensor Test" function was selected for this test. The verifier checks SDI-12 sensors by sending commands to the sensor under test. It verifies all responses, checking for the correct responses within the specified time constraints. The verifier does not check the electrical compliance of the device and no additional testing for SDI-12 electrical compliance was conducted. The Manta2 was compliant with SDI-12 version 1.3 requirements based on the verifier results.

\section{Laboratory Testing}

Testing of the Manta2 sensors was conducted at the USGS HIF. When applicable, National Institute of Standards and Technology (NIST)-traceable chemical standards were used as known references against which the sensors' performances were evaluated. Water equilibrated with an atmosphere containing varying amounts of oxygen was used as the known reference for 
DO measurements. No specific testing of the thermistor was performed. All tests not made at room temperature were conducted in either temperature-controlled water baths or temperaturecontrolled environmental test chambers, depending on the sensor tested.

Additional instrumentation was used for secondary confirmation of the chemical standards and DO concentrations. The calibration and test standard values for $\mathrm{SC}$ and $\mathrm{pH}$ were confirmed with an Orion 5 Star Benchtop meter with a four-cell graphite SC sensor (Model $013605 \mathrm{MD}$, accuracy \pm 0.5 percent, $+0.01 \mu \mathrm{S} / \mathrm{cm}$ [microsiemens per centimeter]) and a ROSS Ultra combination $\mathrm{pH}$ glass electrode (Model 8102BNUWP, accuracy $\pm 0.01 \mathrm{pH}$ units). The Orion $\mathrm{pH}$ and SC meter was calibrated with certified NIST-traceable standards that were different than the test standards. Theoretical DO values were calculated with data from a NISTtraceable Setra Model 370 digital barometric pressure gauge ( \pm 0.02 percent full scale) and YSI $4600\left( \pm 0.115^{\circ} \mathrm{C}\right)$ NIST-traceable thermometer. Winkler titrations were done as an independent check of the theoretical DO concentrations. There was no secondary confirmation of the values of the turbidity standards used for calibration and testing.

$\mathrm{pH}$

Sensors for $\mathrm{pH}$ on the two Manta2 sondes (serial numbers MT11131387 and MT11131388) were tested in a temperature-controlled environmental test chamber. The $\mathrm{pH}$ solutions used as calibration and test standards (table 2) were NIST-traceable, certified at $25{ }^{\circ} \mathrm{C}$, and were rated more accurate than the sensor under test. The $\mathrm{pH}$ standards were supplied with temperature compensation tables that provided the temperature-adjusted standard value; however, standard temperature compensation tables for $\mathrm{pH} 3.0$ covered only $15{ }^{\circ} \mathrm{C}$ to $40{ }^{\circ} \mathrm{C}$. The sensors were evaluated at four test temperatures - 5, 15, 25, and $40{ }^{\circ} \mathrm{C}$ - over a test range of $\mathrm{pH}$ 3.0 to $\mathrm{pH}$ 11.00. Calibration standards, test standards, and the test sondes were allowed to equilibrate overnight in the environmental chamber to the test temperature prior to calibration and data collection. Differences between the Manta2s measured $\mathrm{pH}$ and the test standard value were used to determine sensor accuracy.

Table 2. The $\mathrm{pH}$ standards used to test the $\mathrm{pH}$ sensor of the Eureka Manta2 3.5 water-quality multiprobe sonde and standard specifications at 25 degrees Celsius.

$\left[{ }^{\circ} \mathrm{C}\right.$, degrees Celsius]

\begin{tabular}{lcl}
\hline pH value & Accuracy at $25^{\circ} \mathrm{C}$ & \multicolumn{1}{c}{ Test use } \\
\hline 1.679 & \pm 0.01 & Calibration \\
3.0 & \pm 0.01 & Measurement \\
4.005 & \pm 0.01 & Measurement \\
6.865 & \pm 0.01 & Measurement \\
7.000 & \pm 0.01 & Calibration \\
7.413 & \pm 0.01 & Measurement \\
9.18 & \pm 0.01 & Measurement \\
10.0 & \pm 0.01 & Measurement \\
11.0 & \pm 0.01 & Measurement \\
12.45 & \pm 0.05 & Calibration \\
\hline
\end{tabular}

Each sensor was calibrated at each test temperature using two $\mathrm{pH}$ calibration standards that bracketed the value of the $\mathrm{pH}$ test standard per the USGS "National Field Manual for the 
Collection of Water-Quality Data" (NFM) recommendations (Ritz and Collins, 2008). Two calibration ranges - $\mathrm{pH} 1.679$ to $\mathrm{pH} 7.00$ and $\mathrm{pH} 7.00$ to $\mathrm{pH} 12.45$-were used, depending on the value of the test standard. The calibration procedure was in accordance with the NFM recommendations (Ritz and Collins, 2008) and the Manta2 user's manual for a multipoint calibration, beginning with the $\mathrm{pH} 7.00$ buffer value. During testing, the sensor was triple rinsed with the $\mathrm{pH}$ test standard and allowed to equilibrate in a test standard for an additional 15 minutes prior to making a measurement or until the standard's temperature was within $\pm 1.0^{\circ} \mathrm{C}$ of the desired test temperature prior to the measurement. A YSI 4600 NIST-traceable temperature probe was used to determine the solution's temperature in the environmental chamber. A laptop running Eureka Water Probes Manta 2.0 control software was used to display and record the sonde readings. Temperatures (from YSI 4600 thermometer and sonde) and $\mathrm{pH}$ values were recorded at 30-second intervals 20 times for each test standard and temperature.

\section{Specific Conductance at $25^{\circ} \mathrm{C}$}

The SC sensors on the two Manta2s were tested over a range of SC and temperatures in a temperature-controlled environmental test chamber. Both Manta2s were tested over the same range of SC and temperature. The potassium chloride (KCL) SC solutions (table 3) used as test standards were NIST traceable, certified at $25^{\circ} \mathrm{C}$, and more accurate than the sensor's accuracy limits. The standards were shipped with temperature-compensation tables that provided the temperature-adjusted SC values. Prior to testing, each test sensor was triple rinsed with deionized (DI) water and with the test standard. The two sensors were calibrated at 0 and 1,000 microsiemens per centimeter $(\mu \mathrm{S} / \mathrm{cm})$ at $25^{\circ} \mathrm{C}$ before testing, and the sondes and the testing standards were allowed to equilibrate overnight to the test chamber temperature prior to data collection. Sensors were tested at four test temperatures: $5,15,25$, and $40{ }^{\circ} \mathrm{C}$. During testing, the sensor was triple rinsed with the SC test standard and allowed to equilibrate in a test standard until the standard's temperature was within $\pm 0.5^{\circ} \mathrm{C}$ of the desired test temperature prior to making a measurement.

A YSI 4600 NIST-traceable temperature probe was used to monitor solution temperature during testing in the environmental chamber. A laptop running Eureka Water Probes Manta 2.0 control software was used to display and record the test sonde's readings. Temperatures (from YSI 4600 thermometer and test sonde) and SC at $25{ }^{\circ} \mathrm{C}$ were recorded at 30 -second intervals 20 times for each test standard and temperature.

Table 3. Conductance standards used to test the conductance sensor of the Eureka Manta2 3.5 waterquality multiprobe sonde and standard specifications at 25 degrees Celsius.

$\left[{ }^{\circ} \mathrm{C}\right.$, degrees Celsius; $\mu \mathrm{S} / \mathrm{cm}$, microsiemens per centimeter; \% percent]

\begin{tabular}{cccl}
\hline $\begin{array}{c}\text { Specific conductance } \\
\text { at } 25^{\circ} \mathrm{C} \\
(\boldsymbol{\mu S} / \mathbf{c m})\end{array}$ & \multicolumn{2}{c}{ Accuracy at $25^{\circ} \mathrm{C}$} & Test use \\
\cline { 2 - 3 } & $(\boldsymbol{\mu S} / \mathbf{c m})$ & (percent) & \\
\hline 99.9 & \pm 1.01 & \pm 1.01 & Measurement \\
$1,000.0$ & \pm 10 & \pm 1 & Calibration \\
$1,412.0$ & \pm 3.8 & \pm 0.27 & Measurement \\
$10,000.0$ & \pm 26.00 & \pm 0.26 & Measurement \\
$99,969.0$ & \pm 226.7 & \pm 0.23 & Measurement \\
\hline
\end{tabular}




\section{Dissolved Oxygen}

The DO sensors on the two Manta2s were tested in water with multiple DO concentrations corresponding to 100 percent, 24 percent and 0 percent of atmospheric saturation at varying temperatures (table 4). Prior to testing at each concentration, the DO sensors were calibrated at room temperature in air-saturated water per the NFM (Rounds and others, 2013) and the manufacturer's recommendations. Barometric pressure was measured during testing using a NIST-traceable Setra Model 370 digital pressure gage. Water temperature was measured with a YSI 4600 NIST-traceable temperature probe. Theoretical values for DO were computed and used as the test standard. As an independent check of the theoretical DO test concentrations, Winkler titrations were performed in accordance with Standard Methods 4500-O C Azide Modification (Eaton and others, 2005), with reagents prepared just prior to use.

The 100-percent air saturation solution was created in a ministand pipe (a 16-inch high, 6.25-inch interior diameter acrylic stand pipe fitted with a spigot) in a temperature-controlled environmental test chamber at four different water temperatures. The sonde under test was placed vertically in the ministand pipe. An aquarium pump and air stone were used to saturate the water with air. The entire setup was allowed to run overnight at each test temperature to ensure complete temperature equilibrium and air saturation of the solution. The DO concentrations for air-saturated water at four different temperatures $\left(5,15,25\right.$, and $\left.50{ }^{\circ} \mathrm{C}\right)$ were measured two times by each test sonde. Theoretical DO values for each of the 100-percent air saturation solutions tested were calculated (Benson and Krause, 1980). Two samples were collected from the ministand pipe's spigot immediately after each DO measurement and measured by Winkler titration.

For the 24-percent DO saturation solution, the sonde under test was placed vertically in the ministand pipe, and the top of the pipe was sealed with parafilm. Prior to each DO measurement, an air stone was used to sparge the water with a 95-percent nitrogen and a 5percent oxygen gas mixture for at least 1 hour. The DO concentration in the water bath was measured two times by the sonde under test and recorded. Two samples were collected from the ministand pipe's spigot immediately after each DO measurement and measured by Winkler titration. The theoretical DO value for 24-percent saturation solution was calculated with Henry's Law (Henry, 1803) using 762 millimeters of mercury barometric pressure and a water temperature of $24.1^{\circ} \mathrm{C}$. The corresponding Henry's Law constant was calculated to be 758 liters per atmosphere per mole $\left(\mathrm{L}^{*} \mathrm{~atm} / \mathrm{mol}\right)$, which yielded a calculated DO concentration of 2.12 milligrams per liter $(\mathrm{mg} / \mathrm{L})$.

The 0-percent DO saturation solution was created by placing the sonde under test vertically in the ministand pipe and closing off the top with parafilm. Prior to each DO measurement, an air stone was used to sparge the water with dry nitrogen gas for at least 1 hour. The DO concentration in the water bath was measured two times by the sonde under test and recorded. Two samples were collected from the ministand pipe's spigot immediately after each DO measurement and measured by Winkler titration. The temperature of the water bath $\left(23{ }^{\circ} \mathrm{C}\right)$ was measured with an YSI 4600. The theoretical DO value of the test solution was assumed to be 0 and was verified by the Winkler samples. 
Table 4. Dissolved oxygen reference standards.

[DO, dissolved oxygen; \%, percent; mm Hg, millimeter mercury; ${ }^{\circ} \mathrm{C}$, degrees Celsius; $\mathrm{mg} / \mathrm{L}$, milligrams per liter]

\begin{tabular}{ccccc}
\hline $\begin{array}{c}\text { Do saturation } \\
\text { (percent) }\end{array}$ & $\begin{array}{c}\text { Barometric } \\
\text { pressure } \\
(\mathrm{mm} \mathrm{Hg})\end{array}$ & $\begin{array}{c}\text { Water bath } \\
\text { temperature } \\
\left({ }^{\circ} \mathrm{C}\right)\end{array}$ & $\begin{array}{c}\text { Theoretical DO } \\
(\mathrm{mg} / \mathrm{L})\end{array}$ & Source gas \\
\hline $100^{1}$ & 763 & 4.4 & 13.02 & atmosphere \\
& 760 & 15.4 & 10.01 & \\
& 765 & 23.2 & 8.69 & \\
$24^{2}$ & 760 & 49 & 5.75 & $95 \% \mathrm{~N}_{2}, 5 \% \mathrm{O}_{2}$ \\
0 & 762 & 23 & 2.2 & $100 \% \mathrm{~N}_{2}$ \\
\hline
\end{tabular}

${ }^{1}$ Theoretical values determined from Benson and Krause dissolved oxygen equation for freshwater.

${ }^{2}$ Theoretical values determined from Henry's Law.

Turbidity

A turbidity sensor on one Manta2 (serial number MT11131388) was evaluated for accuracy at room temperature. Test results were based upon a two-point turbidity sensor calibration with ultrapure DI water (0 nephelometric turbidity units [NTU]), and a 100-NTU StablCal standard. The USGS recommends that turbidity measurements with ISO 7027compliant sensors (such as the tested sensor) be expressed in formazine nephelometric units (FNU) to denote the optical methods used by the sensor. Conversion of sample measurements from FNU to NTU usually requires development of site-specific conversion equations for the range of turbidities experienced. For ease of comparison, all sensor data are reported in the same units as the standards - NTU. Because the sensors are tested in turbidity standards, NTU is equal to FNU by definition (American Society for Testing and Materials (ASTM) D7725-12, 1.5.1). The sensor was calibrated and tested in ultrapure DI water and StablCal turbidity standards of $10 ; 20 ; 40 ; 100 ; 400 ; 800 ; 1,000 ; 2,000 ; 2,500 ;$ and 3,000 NTU. All standards were either undiluted StablCal standards or dilutions of the 4,000 NTU formazin/StablCal stock. The turbidity standards were manually resuspended without aeration immediately prior to all sensor measurements.

\section{Laboratory Test Results}

Test results are presented in plots of mean error with vertical error bars by sensor type and test temperatures. The error bars for each parameter tested were calculated assuming the calibration and test standards' accuracy ranges were for two standard deviations and were limited to a rectangular probability distribution (United Kingdom Accreditation, 2007). While no specific testing of the thermistor was performed, the Manta 2 thermistor did perform within the expected accuracy limits of the test setup $\left( \pm 1.2^{\circ} \mathrm{C}\right)$. 
$\mathrm{pH}$

Figures 5 through 12 show the differences between the $\mathrm{pH}$ values from the two Manta2 readings and the known test standard $\mathrm{pH}$ values at temperatures of $5,15,25$, and $40{ }^{\circ} \mathrm{C}$. Differences are shown with error bars that reflect the combined calibration and test standards' accuracy. One Manta2 (MT11131387) performed within manufacturer specifications and the NFM recommendations in all $\mathrm{pH}$ buffers at all temperatures tested. The other Manta2 (MT11131388) was outside manufacturer specifications and NFM recommendations in $\mathrm{pH}$ buffer 11.16 at $15^{\circ} \mathrm{C}$ (fig. 7) and $\mathrm{pH}$ buffer 10.78 at $40{ }^{\circ} \mathrm{C}$ (fig. 11).

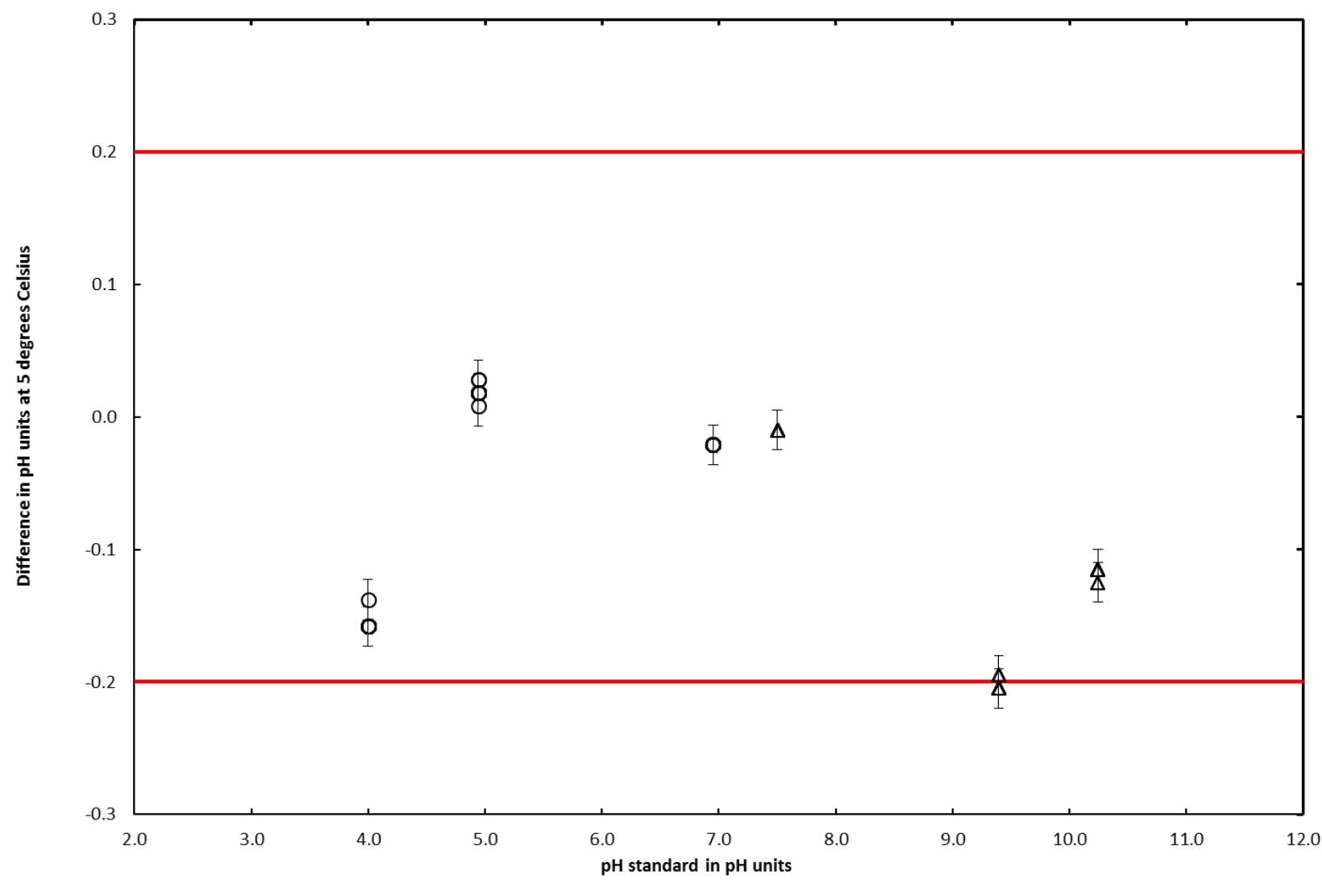

Figure 5. Graph showing difference in $\mathrm{pH}$ units between the Eureka Manta2 3.5 water-quality multiprobe sonde (serial number MT11131388) pH sensor calibrated at two pH ranges and pH standards at 5 degrees Celsius plotted with manufacturer and the U.S. Geological Survey "National Field Manual for the Collection of Water-Quality Data" accuracy limits. Error bars reflect the combined uncertainty of the calibration and test standards. 


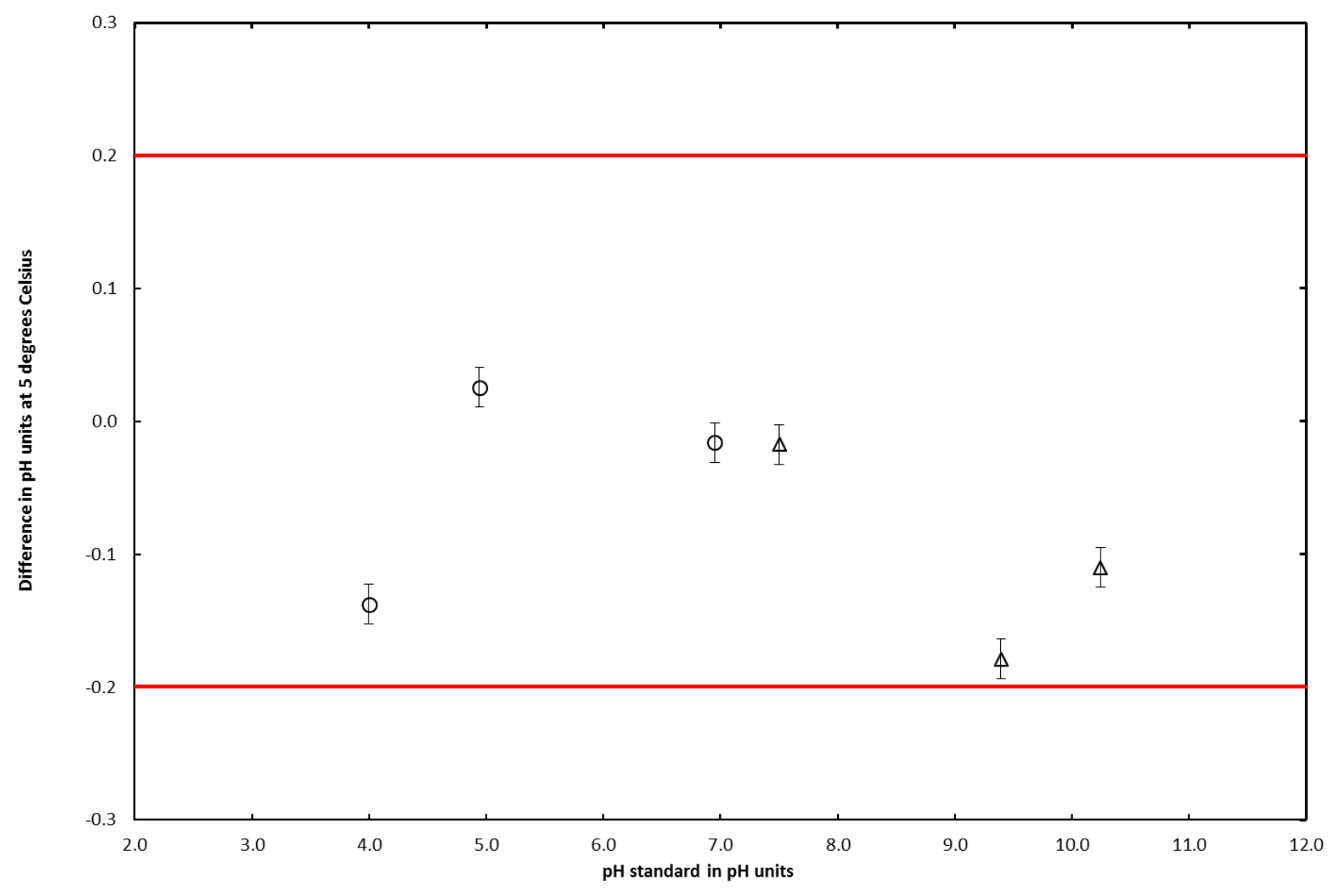

O MT11131387 CALIBRATION RANGE 1.668 TO 7.087 MANTA2 AND NFM LIMIT $\quad \Delta \quad$ MT11131387 CALIBRATION RANGE 7.087 TO 11.283

Figure 6. Graph showing difference in $\mathrm{pH}$ units between the Eureka Manta2 3.5 water-quality multiprobe sonde (serial number MT11131387) pH sensor calibrated at two pH ranges and pH standards at 5 degrees Celsius plotted with manufacturer and the U.S. Geological Survey "National Field Manual for the Collection of Water-Quality Data" accuracy limits. Error bars reflect the combined uncertainty of the calibration and test standards. 


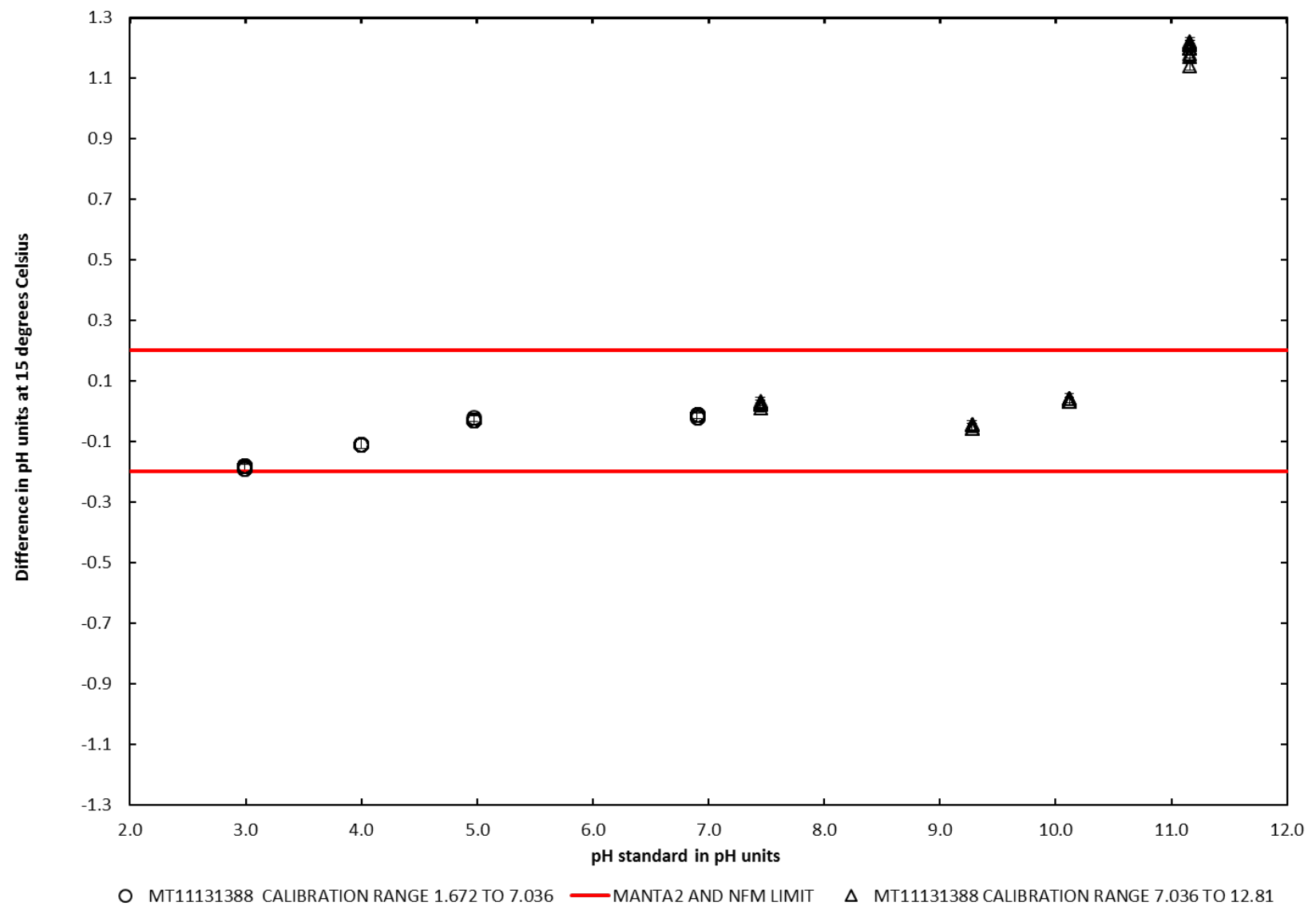

Figure 7. Graph showing difference in $\mathrm{pH}$ units between the Eureka Manta2 3.5 water-quality multiprobe sonde (serial number MT11131388) pH sensor calibrated at two $\mathrm{pH}$ ranges and $\mathrm{pH}$ standards at 15 degrees Celsius plotted with manufacturer and the U.S. Geological Survey "National Field Manual for the Collection of Water-Quality Data" accuracy limits. Error bars reflect the combined uncertainty of the calibration and test standards. 


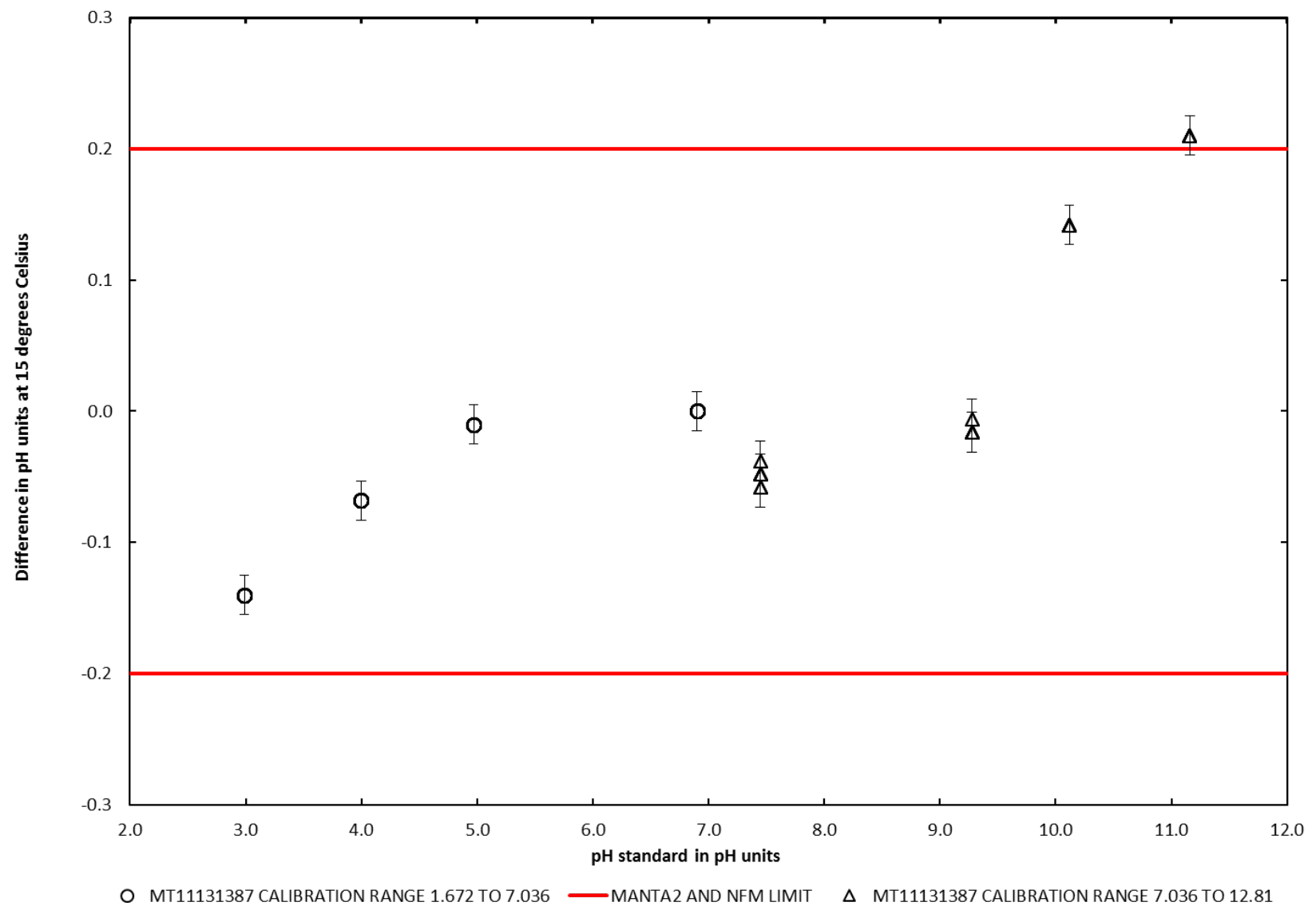

Figure 8. Graph showing difference in $\mathrm{pH}$ units between the Eureka Manta2 3.5 water-quality multiprobe sonde (serial number MT11131387) $\mathrm{pH}$ sensor calibrated at two $\mathrm{pH}$ ranges and $\mathrm{pH}$ standards at 15 degrees Celsius plotted with manufacturer and the U.S. Geological Survey "National Field Manual for the Collection of Water-Quality Data" accuracy limits. Error bars reflect the combined uncertainty of the calibration and test standards. 


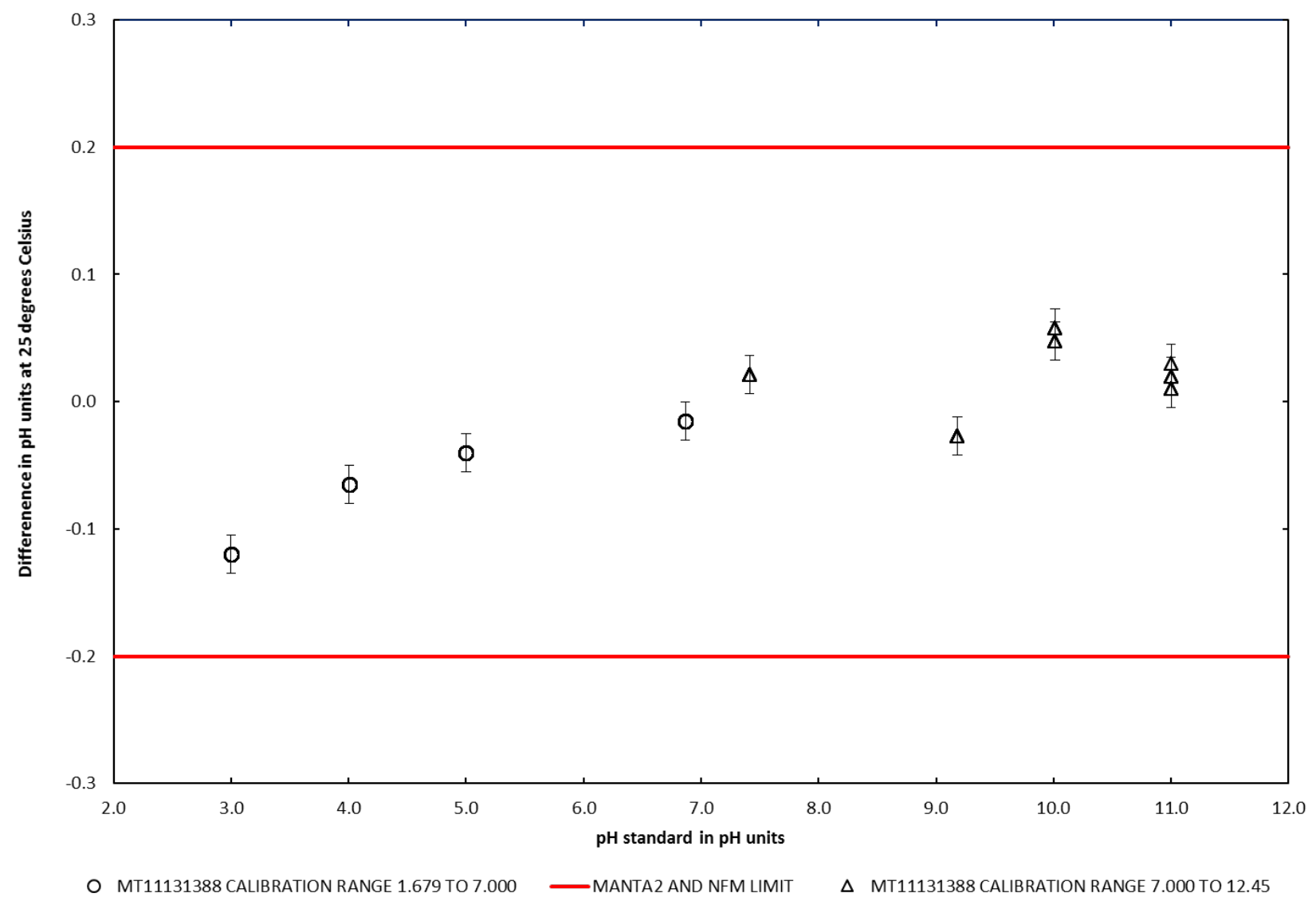

Figure 9. Graph showing difference in $\mathrm{pH}$ units between the Eureka Manta2 3.5 water-quality multiprobe sonde (serial number MT11131388) pH sensor calibrated at two $\mathrm{pH}$ ranges and $\mathrm{pH}$ standards at 25 degrees Celsius plotted with manufacturer and the U.S. Geological Survey "National Field Manual for the Collection of Water-Quality Data" accuracy limits. Error bars reflect the combined uncertainty of the calibration and test standards. 


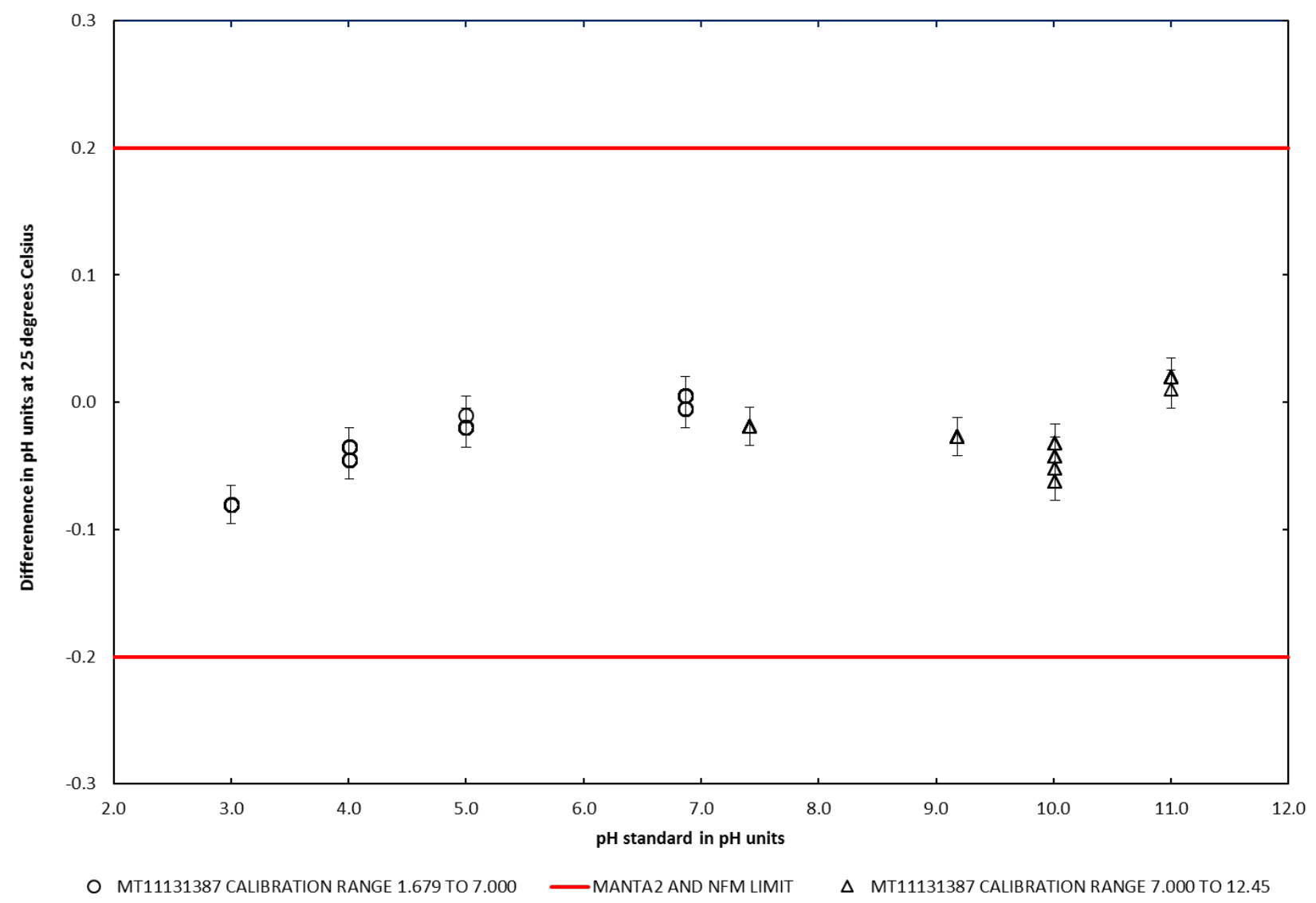

Figure 10. Graph showing difference in $\mathrm{pH}$ units between the Eureka Manta2 3.5 water-quality multiprobe sonde (serial number MT11131387) $\mathrm{pH}$ sensor calibrated at two $\mathrm{pH}$ ranges and $\mathrm{pH}$ standards at 25 degrees Celsius plotted with manufacturer and the U.S. Geological Survey "National Field Manual for the Collection of Water-Quality Data" accuracy limits. Error bars reflect the combined uncertainty of the calibration and test standards. 


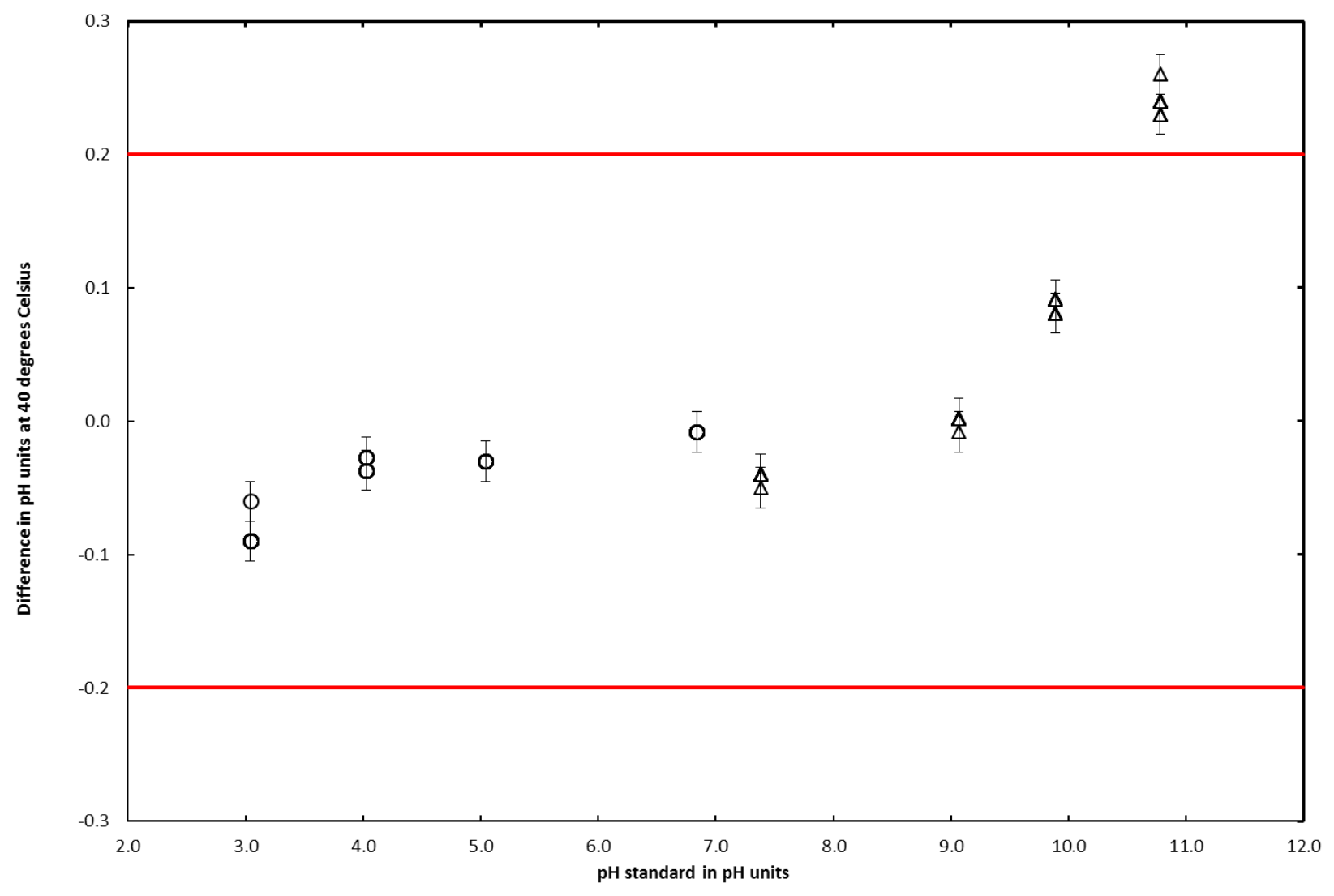

O MT11131388 CALIBRATION RANGE 1.694 TO 6.970 —MANTA2 AND NFM LIMIT $\quad \Delta \quad$ MT11131388 CALIBRATION RANGE 6.970 TO 11.98

Figure 11. Graph showing difference in $\mathrm{pH}$ units between the Eureka Manta2 3.5 water-quality multiprobe sonde (serial number MT11131388) pH sensor calibrated at two $\mathrm{pH}$ ranges and $\mathrm{pH}$ standards at 40 degrees Celsius plotted with manufacturer and the U.S. Geological Survey "National Field Manual for the Collection of Water-Quality Data" accuracy limits. Error bars reflect the combined uncertainty of the calibration and test standards. 


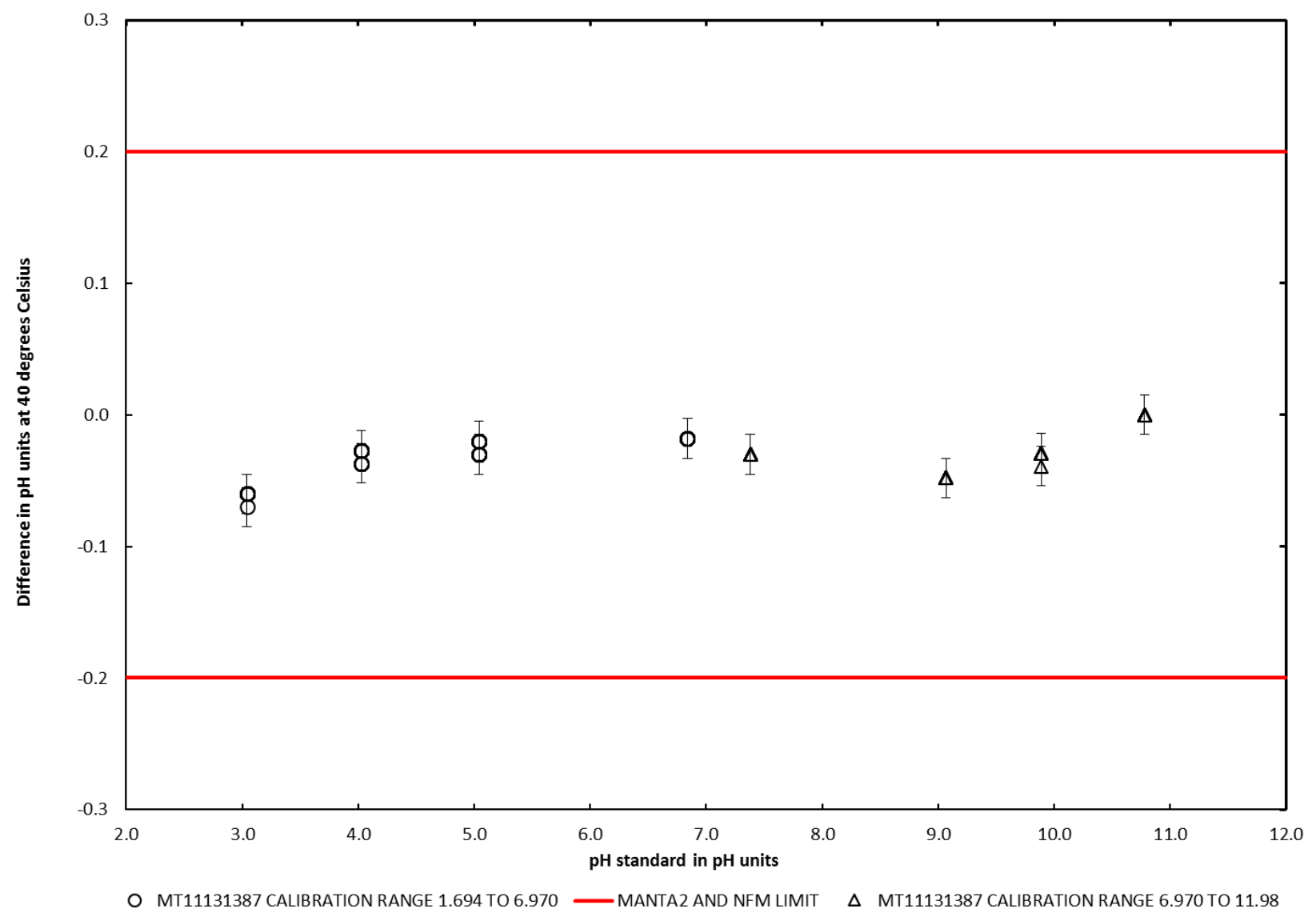

Figure 12. Graph showing difference in $\mathrm{pH}$ units between the Eureka Manta2 3.5 water-quality multiprobe sonde (serial number MT11131387) $\mathrm{pH}$ sensor calibrated at two $\mathrm{pH}$ ranges and $\mathrm{pH}$ standards at 40 degrees Celsius plotted with manufacturer and the U.S. Geological Survey" National Field Manual for the Collection of Water-Quality Data" accuracy limits. Error bars reflect the combined uncertainty of the calibration and test standards.

\section{Specific Conductance at $25^{\circ} \mathrm{C}$}

Figures 13 through 20 show the percent difference between the values from the two Manta2 sensor readings and the known test standard values during SC testing at 5, 15, 25, and $40{ }^{\circ} \mathrm{C}$. Measurements are plotted with error bars that reflect the combined calibration and test standards' accuracy and the uncertainty inherent in the applied temperature correction. This uncertainty arises because the temperature correction coefficient from Standard Methods 2510 B is only approximately the same as that of the KCL test standards. The further the test temperature deviates from $25^{\circ} \mathrm{C}$, the greater the uncertainty in the temperature correction applied to the $\mathrm{KCL}$ test standard measurement (Eaton and others, 2005). At $5^{\circ} \mathrm{C}$ (figs. 13 and 14), both Manta2 sondes were within the NFM recommendations (Radtke and others, 2005) and the manufacturer's specifications in all SC standards. At $15^{\circ} \mathrm{C}$ (figs. 15 and 16), the Manta2 sondes were within the NFM recommendations in all SC standards, and within the manufacturer's specifications in all SC standards except for sonde MT11131388, which exceeded the manufacturer's specifications at $10,000 \mu \mathrm{S} / \mathrm{cm}$. At $25^{\circ} \mathrm{C}$ (figs. 17 and 18), the two Manta2 
sondes met the NFM recommendations in all SC standards and were within the manufacturer's specifications in all SC standards except for sonde MT11131388, which exceeded the manufacturer's specifications at $99.9 \mu \mathrm{S} / \mathrm{cm}$. At $40{ }^{\circ} \mathrm{C}$ (figs. 19 and 20), both Manta2 sondes exceeded the manufacturer's specifications and the NFM recommendations at $99.9 \mu \mathrm{S} / \mathrm{cm}$. The two Manta2 sondes were within the NFM recommendations at 1,412 $\mu \mathrm{S} / \mathrm{cm} ; 10,000 \mu \mathrm{S} / \mathrm{cm}$; and $99,969 \mu \mathrm{S} / \mathrm{cm}$. Sonde MT11131387 exceeded the manufacturer's specifications at $1,412 \mu \mathrm{S} / \mathrm{cm}$ and $10,000 \mu \mathrm{S} / \mathrm{cm}$, and sonde MT11131388 exceeded the manufacturer's specifications at $1,412 \mu \mathrm{S} / \mathrm{cm}$. The Manta2 SC sensors were typically within NFM recommendations except at the lowest value tested.

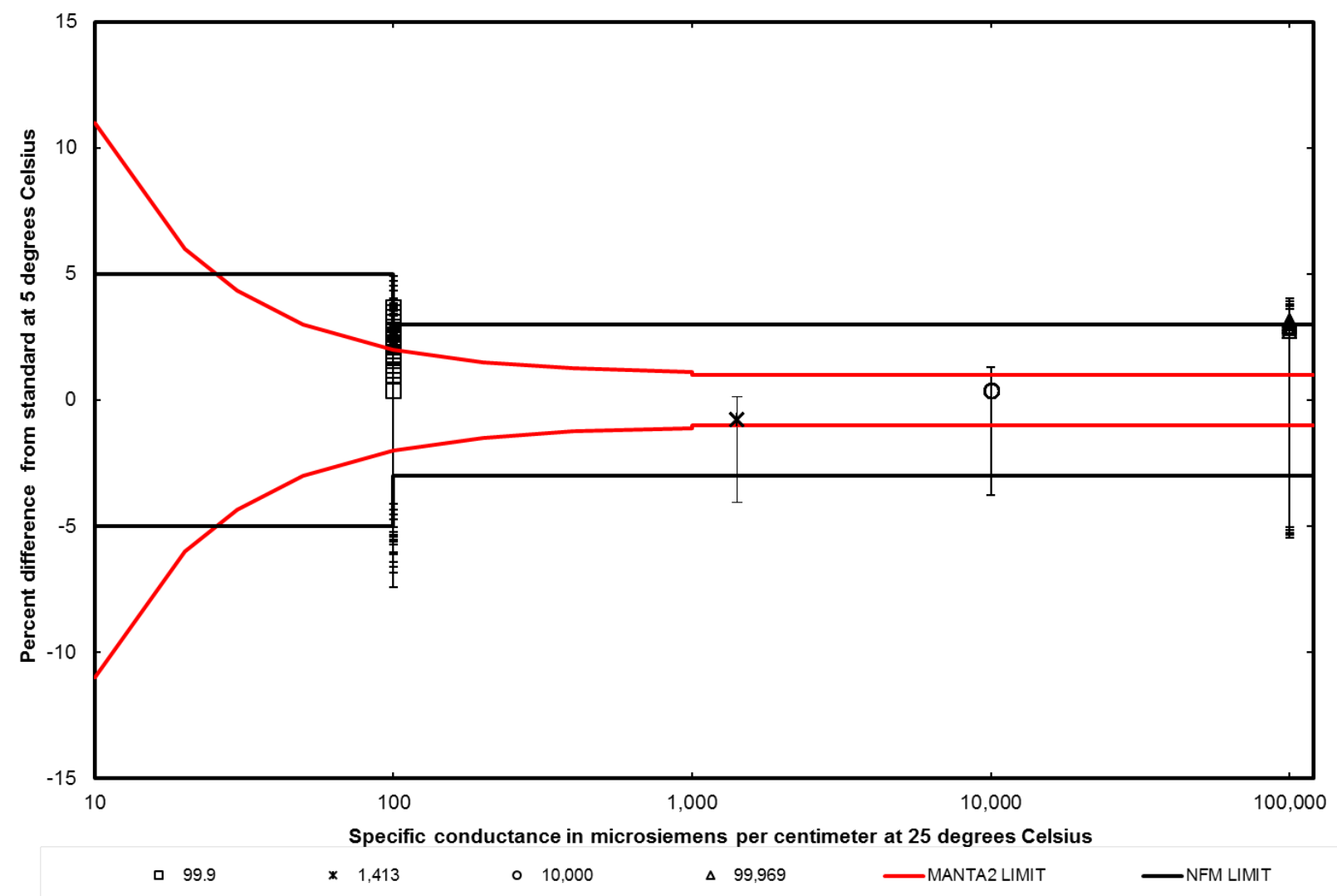

Figure 13. Graph showing percent difference between the Eureka Manta2 3.5 water-quality multiprobe sonde (serial number MT11131388) and the specific conductance standard measured at 5 degrees Celsius. Data are plotted with manufacturer and the U.S. Geological Survey "National Field Manual for the Collection of Water-Quality Data" accuracy limits. Error bars reflect the combined uncertainty of the calibration and test standards and the uncertainty inherent in the applied temperature correction. 


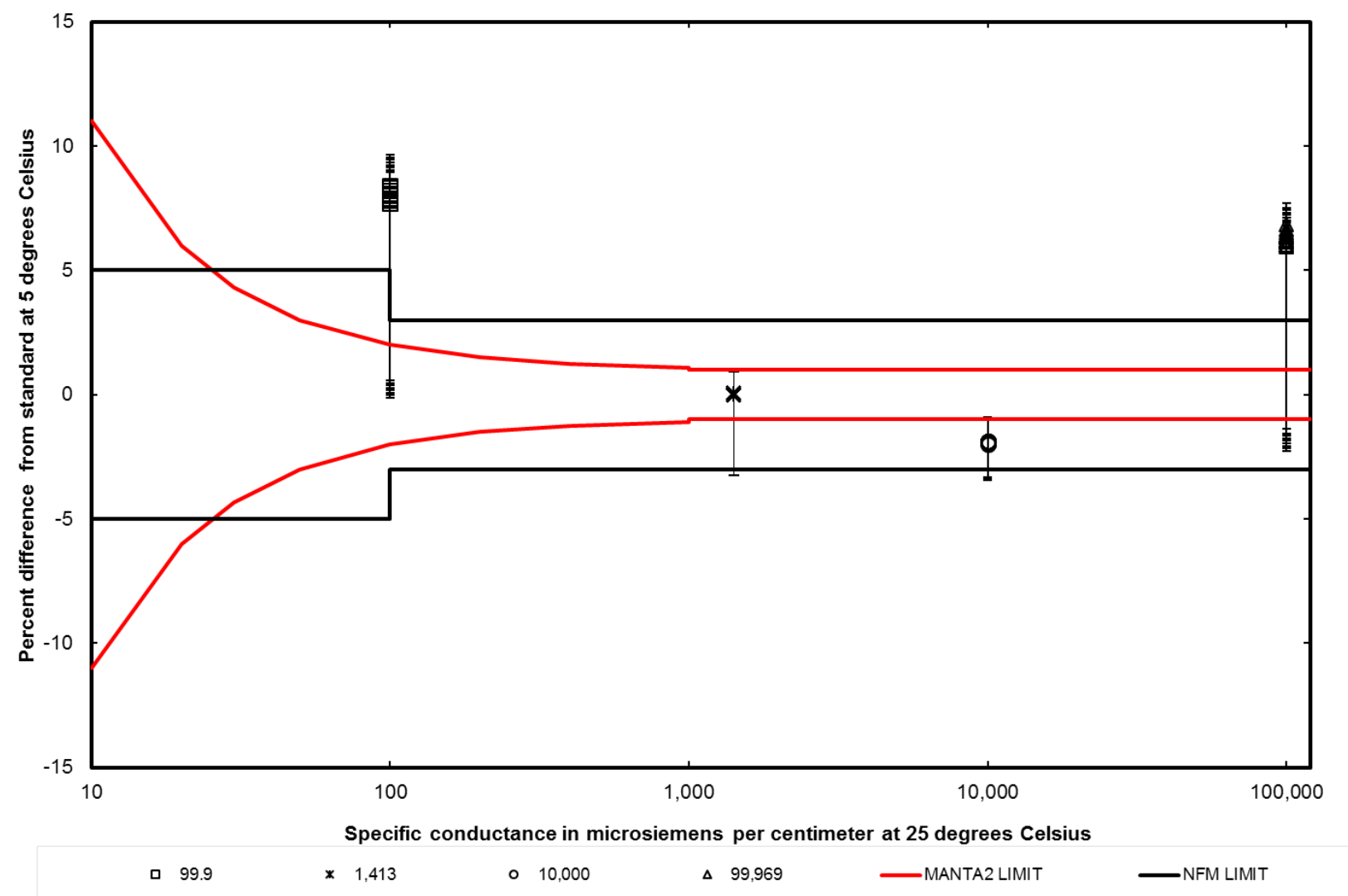

Figure 14. Graph showing percent difference between the Eureka Manta2 3.5 water-quality multiprobe sonde (serial number MT11131387) and the specific conductance standard measured at 5 degrees Celsius. Data are plotted with manufacturer and the U.S. Geological Survey "National Field Manual for the Collection of Water-Quality Data" accuracy limits. Error bars reflect the combined uncertainty of the calibration and test standards and the uncertainty inherent in the applied temperature correction. 


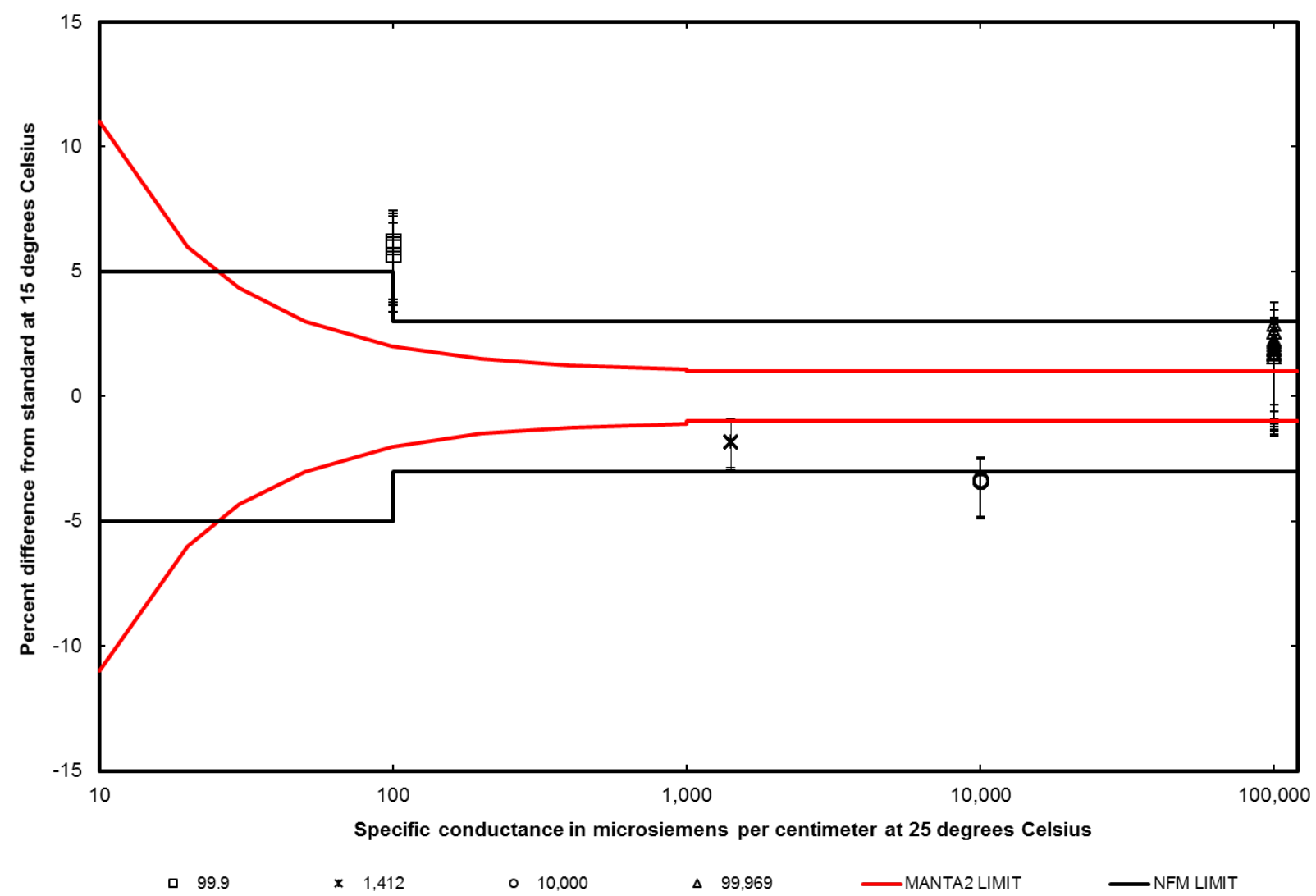

Figure 15. Graph showing average percent difference between the Eureka Manta2 3.5 water-quality multiprobe sonde (serial number MT11131388) and the specific conductance standard measured at 15 degrees Celsius. Data are plotted with manufacturer and the U.S. Geological Survey "National Field Manual for the Collection of Water-Quality Data" accuracy limits. Error bars reflect the combined uncertainty of the calibration and test standards and the uncertainty inherent in the applied temperature correction. 


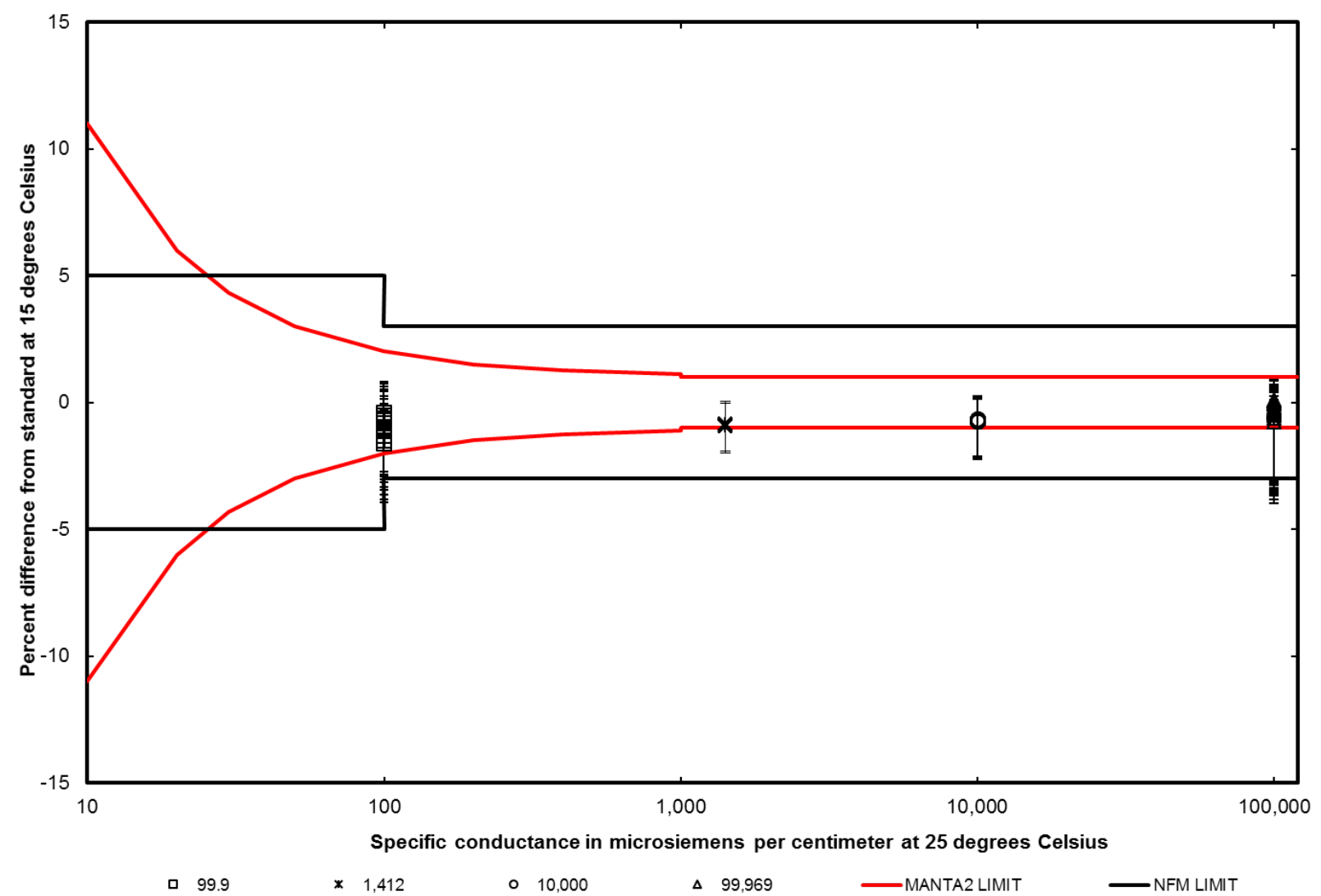

Figure 16. Graph showing average percent difference between the Eureka Manta2 3.5 water-quality multiprobe sonde (serial number MT11131387) and the specific conductance standard measured at 15 degrees Celsius. Data are plotted with manufacturer and the U.S. Geological Survey "National Field Manual for the Collection of Water-Quality Data" accuracy limits. Error bars reflect the combined uncertainty of the calibration and test standards and the uncertainty inherent in the applied temperature correction. 


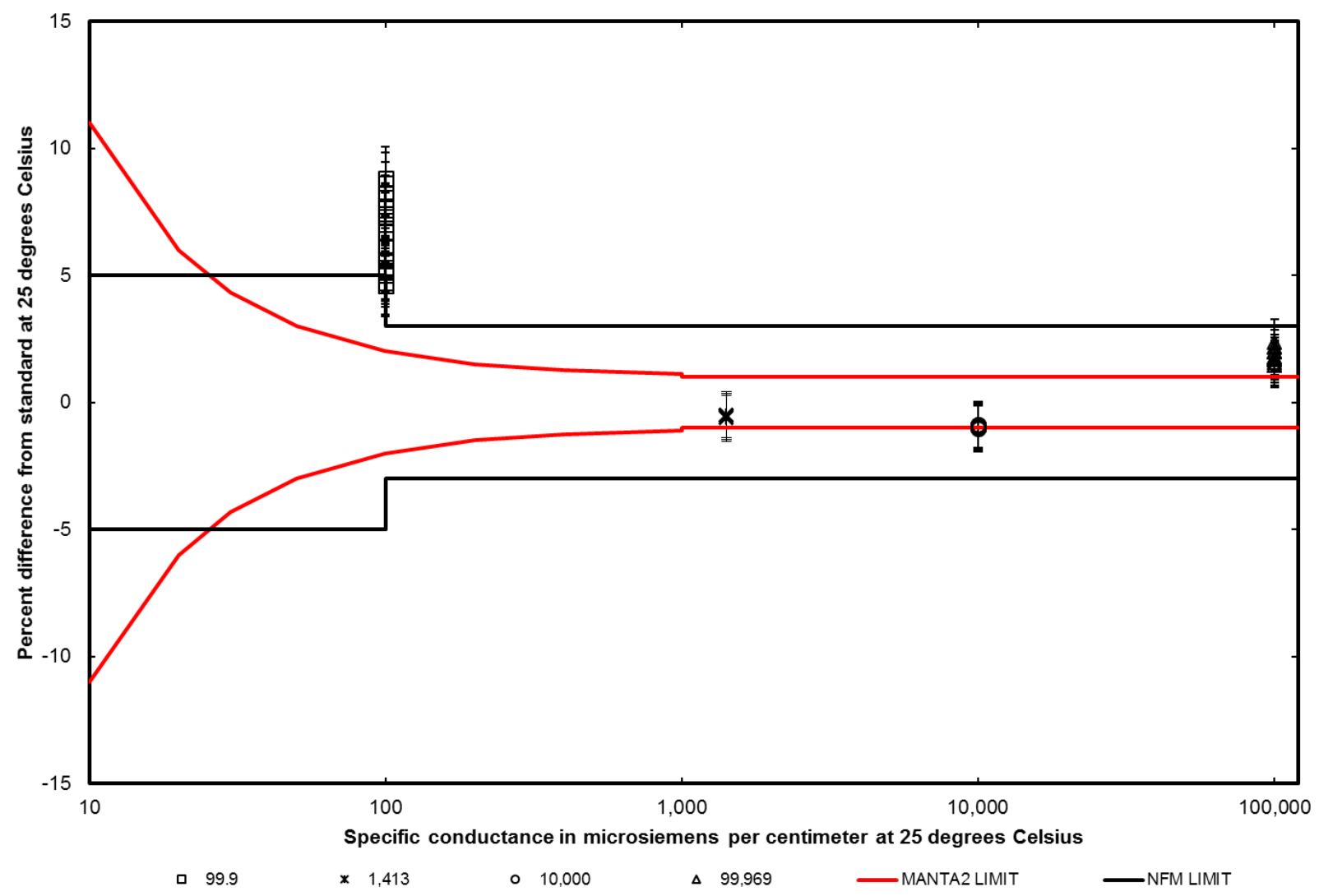

Figure 17. Graph showing percent difference between the Eureka Manta2 3.5 water-quality multiprobe sonde (serial number MT11131388) and the specific conductance standard measured at 25 degrees Celsius. Data are plotted with manufacturer and the U.S. Geological Survey "National Field Manual for the Collection of Water-Quality Data" accuracy limits. Error bars reflect the combined uncertainty of the calibration and test standards. 


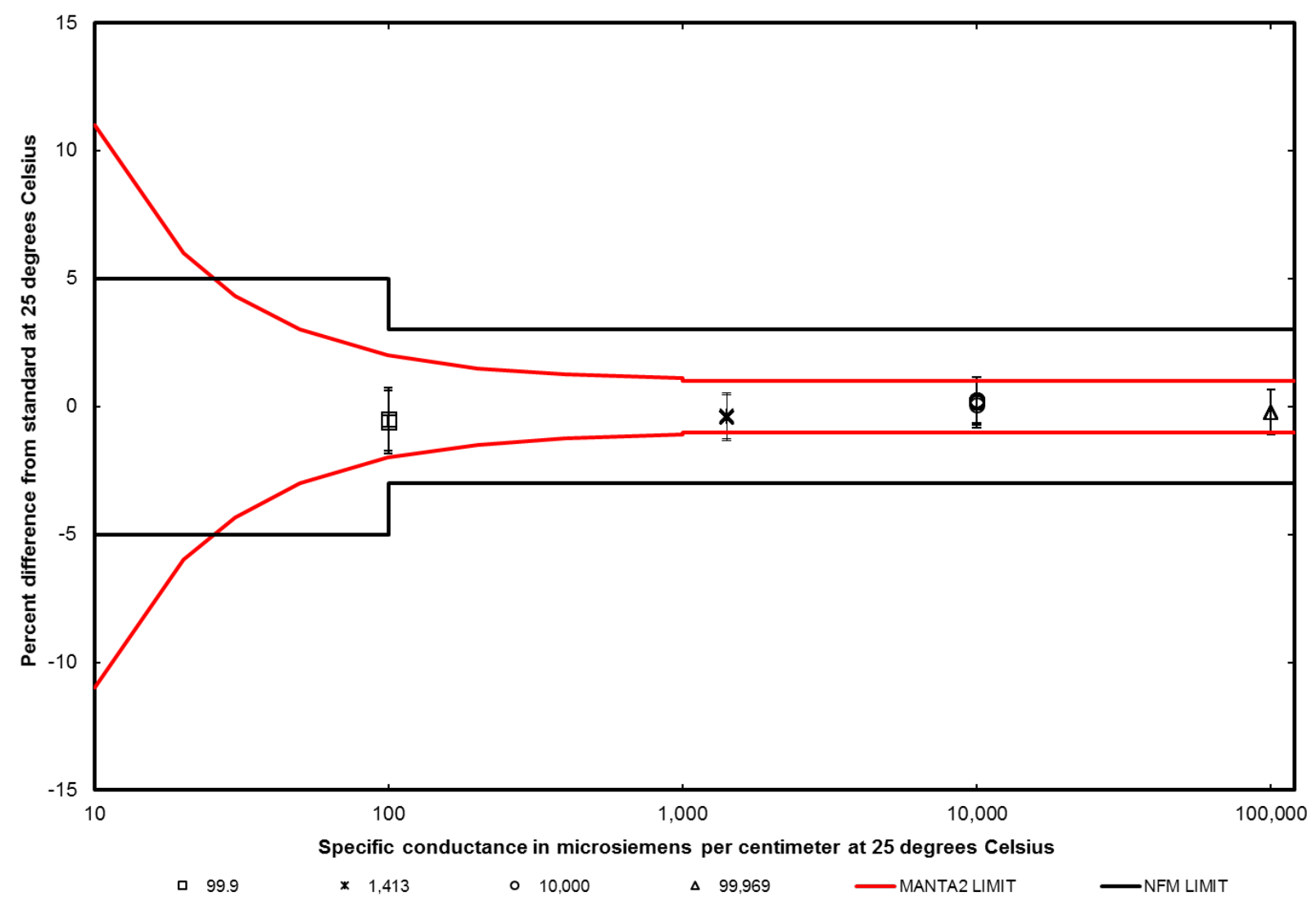

Figure 18. Graph showing percent difference between the Eureka Manta2 3.5 water-quality multiprobe sonde (serial number MT11131387) and the specific conductance standard measured at 25 degrees Celsius. Data are plotted with manufacturer and the U.S. Geological Survey "National Field Manual for the Collection of Water-Quality Data" accuracy limits. Error bars reflect the combined uncertainty of the calibration and test standards. 


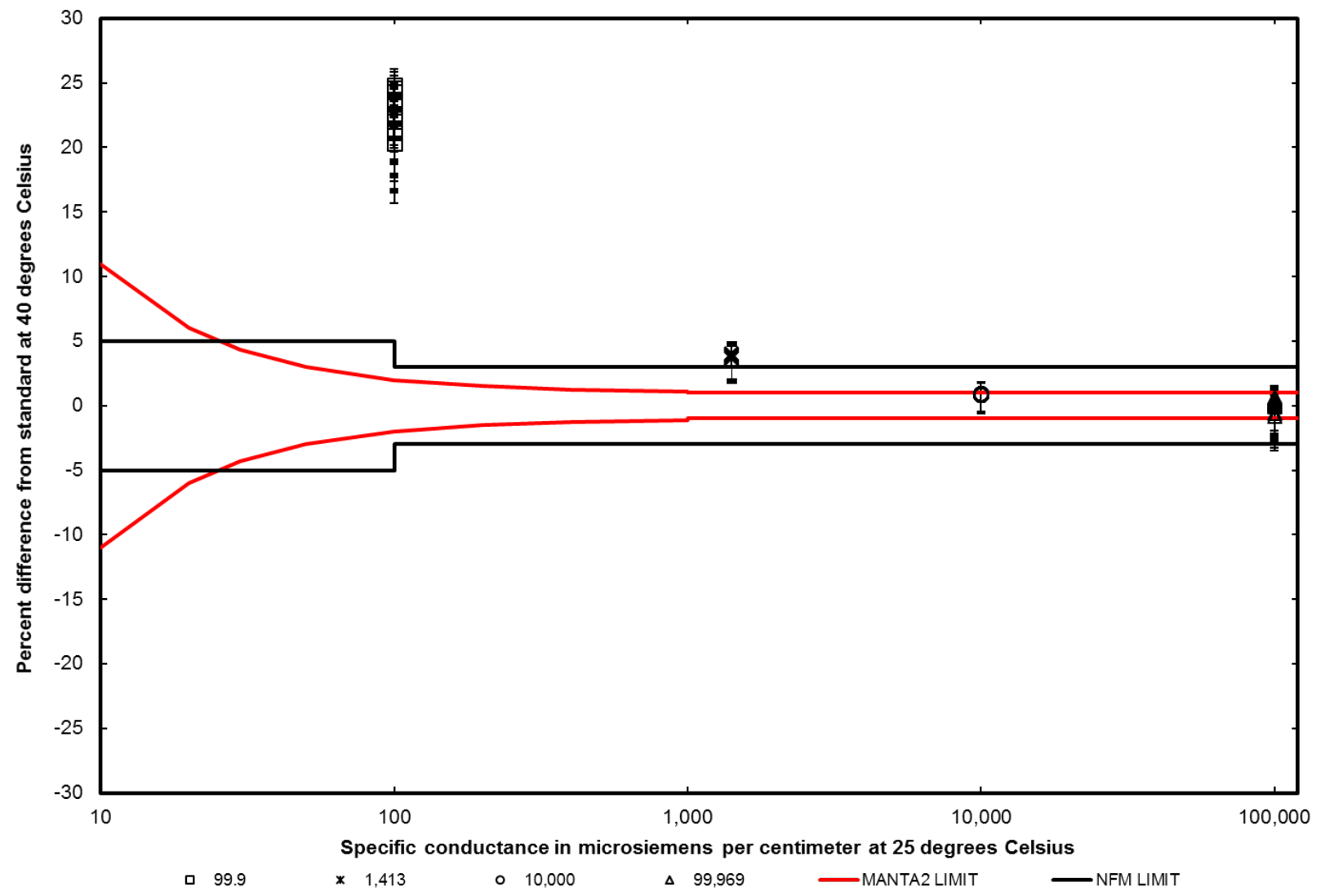

Figure 19. Graph showing percent difference between the Eureka Manta2 3.5 water-quality multiprobe sonde (serial number MT11131388) and the specific conductance standard measured at 40 degrees Celsius. Data are plotted with manufacturer and the U.S. Geological Survey "National Field Manual for the Collection of Water-Quality Data" accuracy limits. Error bars reflect the combined uncertainty of the calibration and test standards and the uncertainty inherent in the applied temperature correction. 


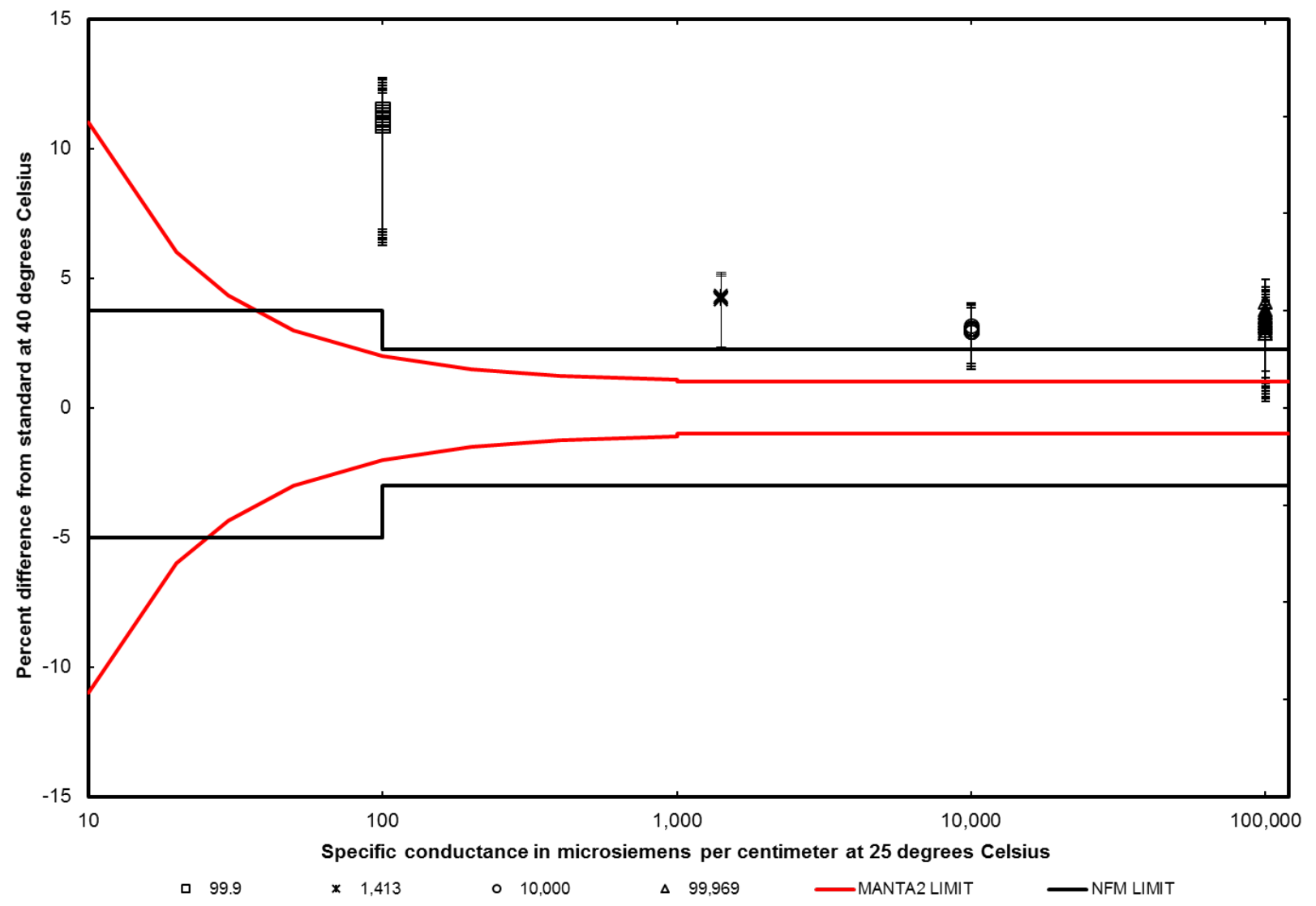

Figure 20. Graph showing percent difference between the Eureka Manta2 3.5 water-quality multiprobe sonde (serial number MT11131387) and the specific conductance standard measured at 40 degrees Celsius. Data are plotted with manufacturer and the U.S. Geological Survey "National Field Manual for the Collection of Water-Quality Data" accuracy limits. Error bars reflect the combined uncertainty of the calibration and test standards and the uncertainty inherent in the applied temperature correction. 


\section{Dissolved Oxygen}

The results of testing the Manta2 DO sensor are shown in figure 21. The difference between the test sonde's readings and the theoretical DO values are plotted along with the difference between the Winkler titrations and the theoretical DO values. The DO sensor tested within the manufacturer specifications and the NFM recommendations at all concentrations.

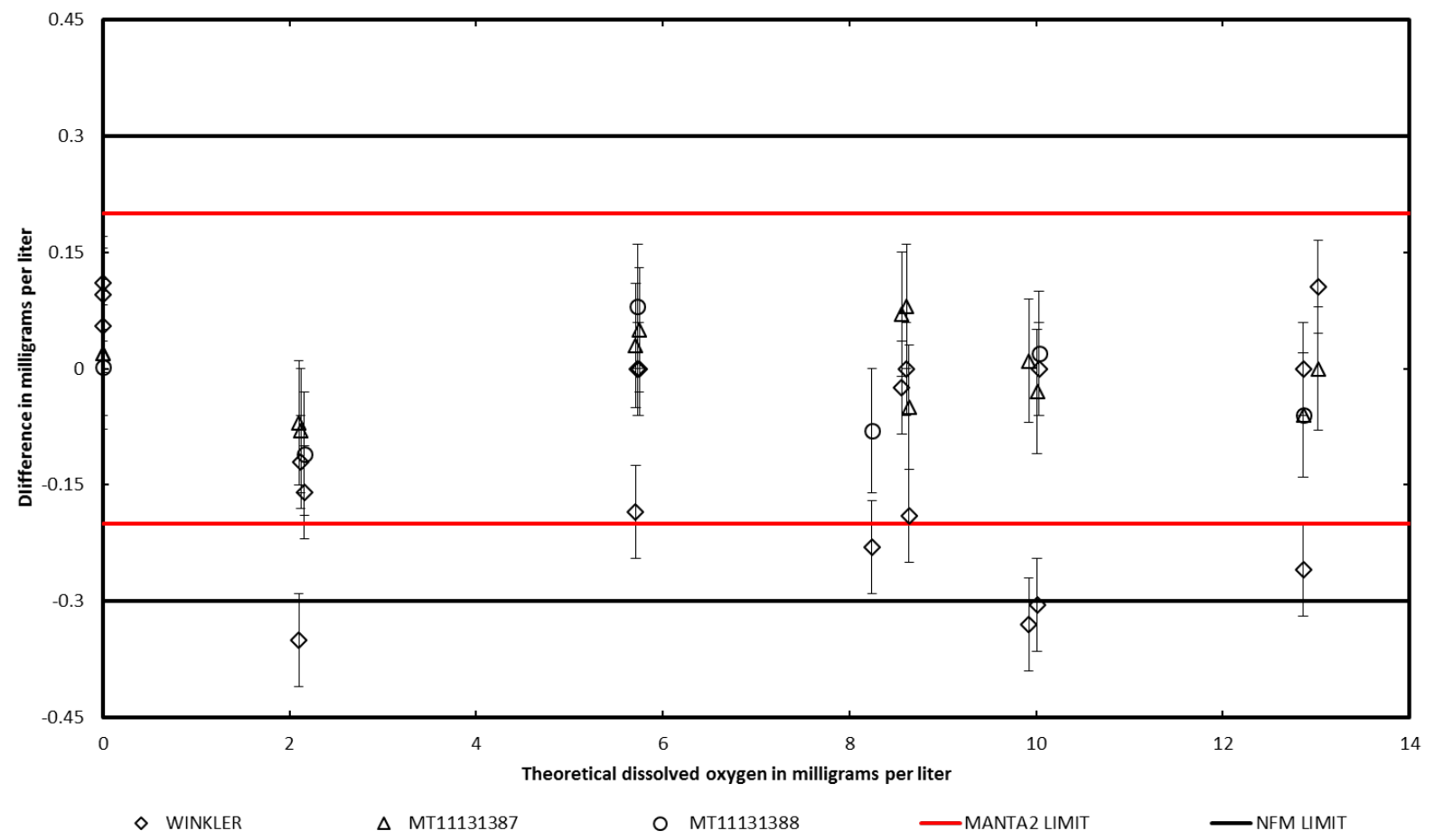

Figure 21. Graph showing difference in milligrams per liter between two Eureka Manta2 3.5 water-quality multiprobe sondes (serial numbers MT11131387 and MT11131388) and theoretical dissolved oxygen concentrations plotted with manufacturer and the U.S. Geological Survey "National Field Manual for the Collection of Water-Quality Data" accuracy limits. Error bars reflect the combined uncertainty of the sensor calibration and error of the calculated theoretical dissolved oxygen concentration. 


\section{Turbidity}

The results from the room-temperature testing of the turbidity sensor with a two-point calibration ( 0 and $100 \mathrm{NTU}$ ) are shown in figure 22 . The difference between the mean of five replicates and the standard turbidity values of $0 ; 10 ; 20 ; 40 ; 100 ; 400 ; 800 ; 1,000 ; 2,000 ; 2,500$; and 3,000 NTU are plotted for each standard. The sensor tested met the \pm 5 percent NFM recommendations, and met the manufacturer's criteria in turbidities up to 3,000 NTU when the uncertainty of the measurement was considered. The average standard deviation of the dataset5 replicates in 11 standards - was 2.79 NTU.

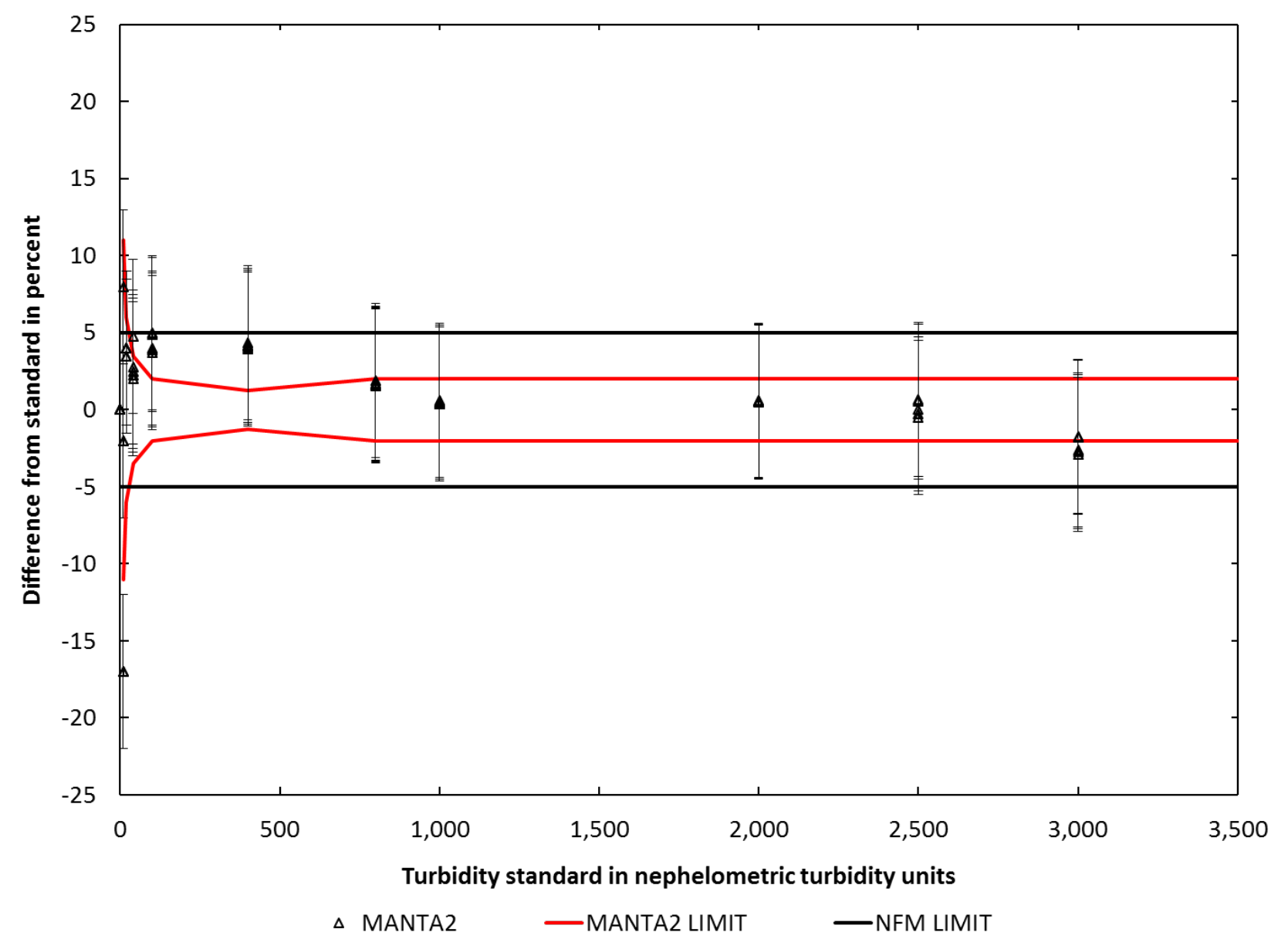

Figure 22. Graph showing average percent differences between the Eureka Manta2 3.5 water-quality multiprobe sonde (serial number MT 11131388) turbidity sensor and ultrapure deionized water $(0$ nephelometric turbidity units [NTU] and StablCal turbidity standards of 10;20;40;100;400;800;1,000; 2,000; 2,500; and 3,000 NTU after a two-point calibration at 0 and 100 NTU. The black lines represent the \pm 5 percent U.S. Geological Survey "National Field Manual for the Collection of Water-Quality Data" accuracy criteria, and the red dash-dot lines represent the manufacturer's technical specifications. Error bars reflect the combined uncertainty of the sensor calibration and test standards. 


\section{Field Test}

\section{Test Procedure}

The Manta2 used in the laboratory testing (serial number MT11131387) was deployed at the HIF's field test site (USGS station 02492620, Pearl River at NSTL Station, Mississippi) (http://waterdata.usgs.gov/usa/nwis/uv?site_no=02492620) from June 24, 2014 to September 5, 2014. The test site is tidally affected and, depending on the discharge, the wind, and the tides, the river can be fresh, brackish, or saltwater. The river can be well mixed, or poorly mixed and stratified in the water column.

The Manta2 3.5 test sonde was deployed inside a stilling well adjacent to a wellmaintained site sonde for 6 weeks with biweekly maintenance. The test sonde was calibrated according to the NFM and manufacturer's guidance for field deployment. Data, including water temperature $\left({ }^{\circ} \mathrm{C}\right), \mathrm{pH}$ (pH units), $\mathrm{SC}(\mu \mathrm{S} / \mathrm{cm})$, and $\mathrm{DO}(\mathrm{mg} / \mathrm{L})$, were logged by a Design Analysis WaterLOG H-500XL every 15 minutes.

Biweekly maintenance of the Manta2 test sonde consisted of cleaning and calibration checks against standards. Fouling and calibration drift corrections for the sensors were calculated in accordance with USGS protocol for correction of field data (Wagner and others, 2006).

The site sonde, a Hydrolab DataSonde 5X, was maintained and checked weekly and calibrated as needed. Quality control (QC) checks during the field test consisted of comparison readings with a YSI 6920 V2-2 field reference sonde temporarily deployed during each weekly site visit to determine fouling drift. The field reference sonde was also checked weekly against standards and calibrated as needed.

During the deployment, the river, as indicated by weekly vertical profiling at the station, was well mixed for the first 2 weeks of the field test. During the last 4 weeks of the field test, the river was not well mixed, experiencing repeated tidal saltwater intrusions. The site sonde, although maintained and verified, developed unforeseen problems with the turbidity and SC sensors. The SC sensor was replaced once during the test and the turbidity sensor was replaced three different times in the 3 weeks following the field test. Three weeks after the completion of the field test, the site sonde experienced a motherboard failure and was replaced with a new sonde. Due to this failure, the turbidity data from the site sonde were not used for the field test comparison.

The field test data used to compare the site sonde and the test sonde were not corrected for fouling or for calibration drift. Previous field tests at the HIF have shown that applying fouling or calibration drift corrections to field test data make comparison analysis unreliable. The uncorrected values for stage varied from a low of -0.92 foot (ft) to a high of $2.34 \mathrm{ft}$ and the uncorrected water temperatures measured by the site sonde ranged from 27.1 to $31.8^{\circ} \mathrm{C}$. The uncorrected $\mathrm{pH}$ values measured by the site sonde during the test ranged from 6.01 to 6.78 . The uncorrected $\mathrm{SC}$ values measured by the site sonde during the test ranged from 51 to $14,410 \mu \mathrm{S} / \mathrm{cm}$ and the uncorrected DO values ranged from $0.02 \mathrm{mg} / \mathrm{L}$ to $9.51 \mathrm{mg} / \mathrm{L}$.

The performance of the Manta2 was determined by the differences between the test sonde and the site sonde. Difference was calculated as the value of the test sonde minus the value of the site sonde. Positive differences indicated a high bias in the test sonde data, and negative differences indicated a low bias in test sonde data.

The recommendations from table $6.8-5$ of chapter 6 of the NFM, "Use of Multiparameter Instruments for Routine Field Measurements" (Gibs and others, 2007), have been adopted by the HIF as acceptance criteria for field testing water-quality sondes (table 5). Because the accuracy 
of each sonde is assumed to meet at least the maximum criteria listed in table 6.8-5, the acceptance criteria is equal to twice the criteria listed in the table. To meet the acceptance criteria, the differences between the Manta2 sensors and the site sonde sensors should be less than or equal to the acceptance criteria.

Table 5. Acceptance criteria for field test comparison of the Eureka Manta2 3.5 water-quality multiprobe sonde and the Hydrolab Data Sonde 5 site sonde.

$\left[{ }^{\circ} \mathrm{C}\right.$, degrees Celsius; $\mu \mathrm{S} / \mathrm{cm}$, microsiemens per centimeter, $\%$, percent; $\mathrm{mg} / \mathrm{L}$, milligrams per liter $]$

\begin{tabular}{ll}
\multicolumn{1}{c}{ Sensor parameter } & \multicolumn{1}{c}{ Acceptance criteria } \\
\hline Temperature $\left({ }^{\circ} \mathrm{C}\right)$ & \pm 0.4 \\
$\mathrm{pH}(\mathrm{pH}$ units) & \pm 0.4 \\
Dissolved oxygen $(\mathrm{mg} / \mathrm{L})$ & \pm 0.6 \\
Specific conductance at $25^{\circ} \mathrm{C}(\mu \mathrm{S} / \mathrm{cm})$ & $\pm 10 \%$ of reading \\
\hline
\end{tabular}

\section{Test Results}

The summary statistics (table 6) for the 6-week test period show that there was good agreement of temperature, $\mathrm{pH}$, and DO data between the Manta2 test sonde and the site sonde. Table 6 also includes the data point count for each parameter for the Manta2 test sonde and the site sonde. The temperature data for the test sonde agreed closely with the site sonde data for the first 5 weeks of the field test (fig. 23, A), with the exception of a few occasional spikes. The difference between the mean temperature for the test sonde data and the mean temperature for the site sonde was $-0.03{ }^{\circ} \mathrm{C}$. During the last week of the field test (fig. 23, $A$ ), there was a notable negative drift, possibly a symptom of the site sonde's motherboard problem that led to the replacement of the site sonde 3 weeks after the conclusion of the field test. The $\mathrm{pH}$ data for the test sonde showed good agreement with the site sonde data during the 6-week field test (fig. 24, $A$ ). The mean difference between the test sonde $\mathrm{pH}$ data and the site sonde was $-0.15 \mathrm{pH}$ unit.

The Manta2 SC data closely agreed with the site sonde data for the first 2 weeks of the field test (fig. 25, $A$ ). The difference between the mean SC for the test sonde and the site sonde was $-118 \mu \mathrm{S} / \mathrm{cm}$, or 11 percent, which was just outside the acceptance criteria in table 5. During the third week of the field test, the station experienced minor tidal saltwater intrusions and the test sonde's SC data exceeded the accuracy limits (fig. $25, A$ ) by a maximum of $-961 \mu \mathrm{S} / \mathrm{cm}$. Starting in the fourth week of the field test, the station experienced tidal saltwater intrusions that progressively increased through the fifth week, peaking in the sixth week before finally decreasing towards the end of the field test. During tidal saltwater intrusions, the test sonde's SC data exceeded the accuracy limits (fig. $25, A$ ) by as much as $-9,300 \mu \mathrm{S} / \mathrm{cm}$. These differences were likely due to a combination of the stratification of the water column during the tidal saltwater intrusions and an inch or two difference in the depth of deployment between the site sonde and the test sonde sensors in the water column. During the last week of the field test, the $\mathrm{SC}$ sensor on the site sonde failed and had to be replaced, resulting in the loss of 4 days of data for both SC and DO from August 30, 2014 to September 2, 2014.

The DO data for the test sonde agreed with the site sonde data for the first 4 days (fig. 26, $A$ ) before a progressively negative drift began, exceeding the accuracy limits by as much as $-2.79 \mathrm{mg} / \mathrm{L}$. This shift in data ceased with the maintenance of the site sonde on August 1, 2014. During the second week, a similar, albeit smaller, drift started and continued until maintenance of the test sonde was conducted on August 7, 2014. This drift exceeded the 
accuracy limits by as much as $-0.61 \mathrm{mg} / \mathrm{L}$. Weeks 3 and 4 of DO data showed a slightly negative bias in the difference between the Manta2 and the site sonde data. During week 5, tidal saltwater intrusions produced rapidly changing SC values at the field test site and a progressively positive difference between the Manta 2 and the site sonde data began, which eventually exceeded the accuracy limits by $4.15 \mathrm{mg} / \mathrm{L}$. The site sonde SC sensor was found to not be functioning correctly and replaced in week 6, resulting in the loss of 4 days of data from August 30, 2014 to September 2, 2014. After replacement, the site sensor and the Manta2 sensor agreed until the end of the test. The difference between the mean DO for the test sonde and the site sonde was $-0.2 \mathrm{mg} / \mathrm{L}$ when compared to the site sonde for the last week of the test.
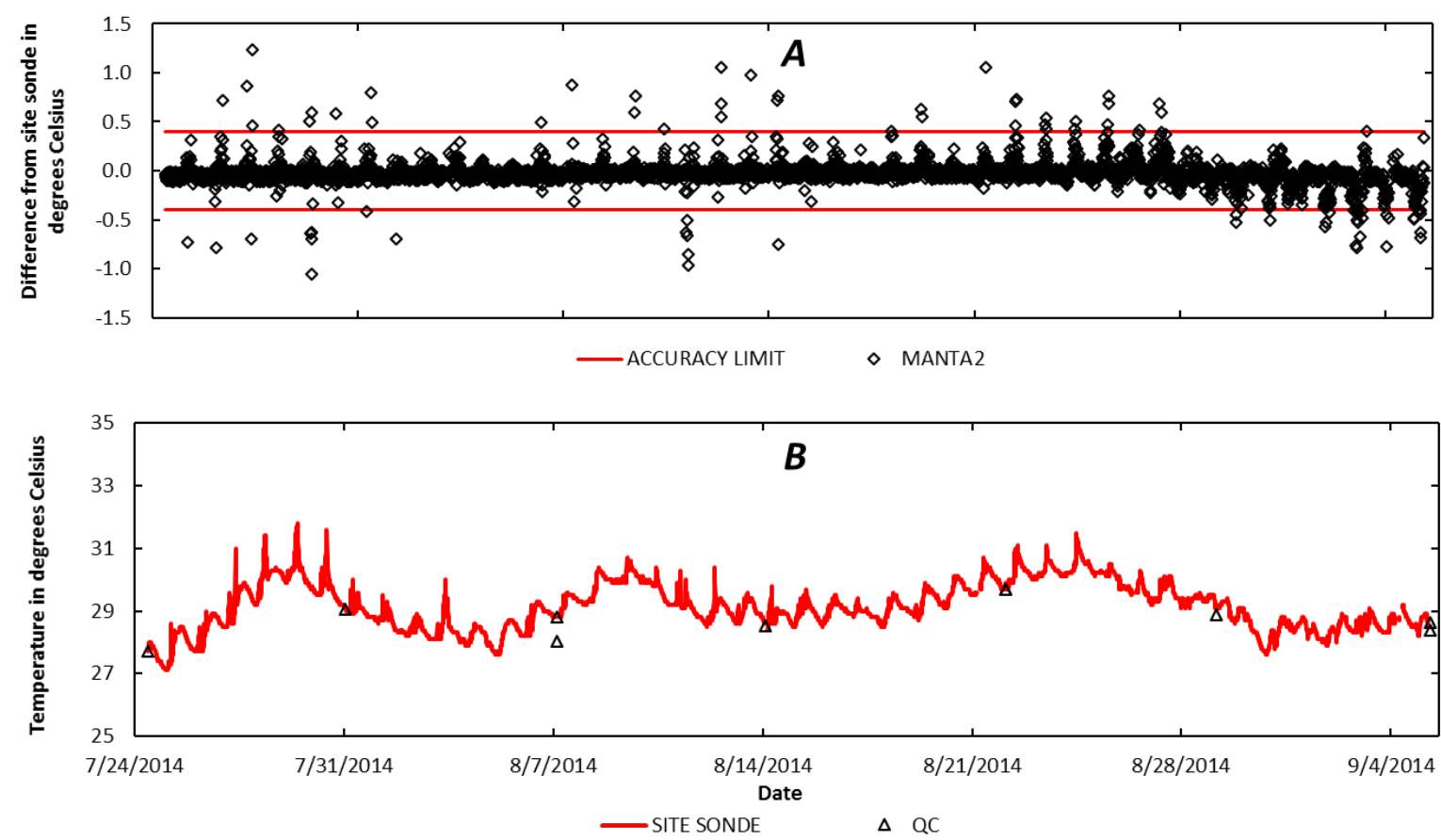

Figure 23. Graphs showing A, temperature differences between the Eureka Manta2 3.5 water-quality multiprobe test sonde with biweekly maintenance and the site sonde at U.S. Geological Survey (USGS) station 02492620 (Pearl River at National Space Technology Laboratories Station, Mississippi) over time (6 weeks), and $B$, temperature versus time for the site sonde and a YSI 6920 V2-2 Quality Control (QC) sonde. Differences for the top chart were calculated by subtracting the site sonde's reading from the test sonde's reading. Accuracy limits are twice the limits recommended in table 6.8-5 of chapter 6 of the USGS "National Field Manual for the Collection of Water-Quality Data." 

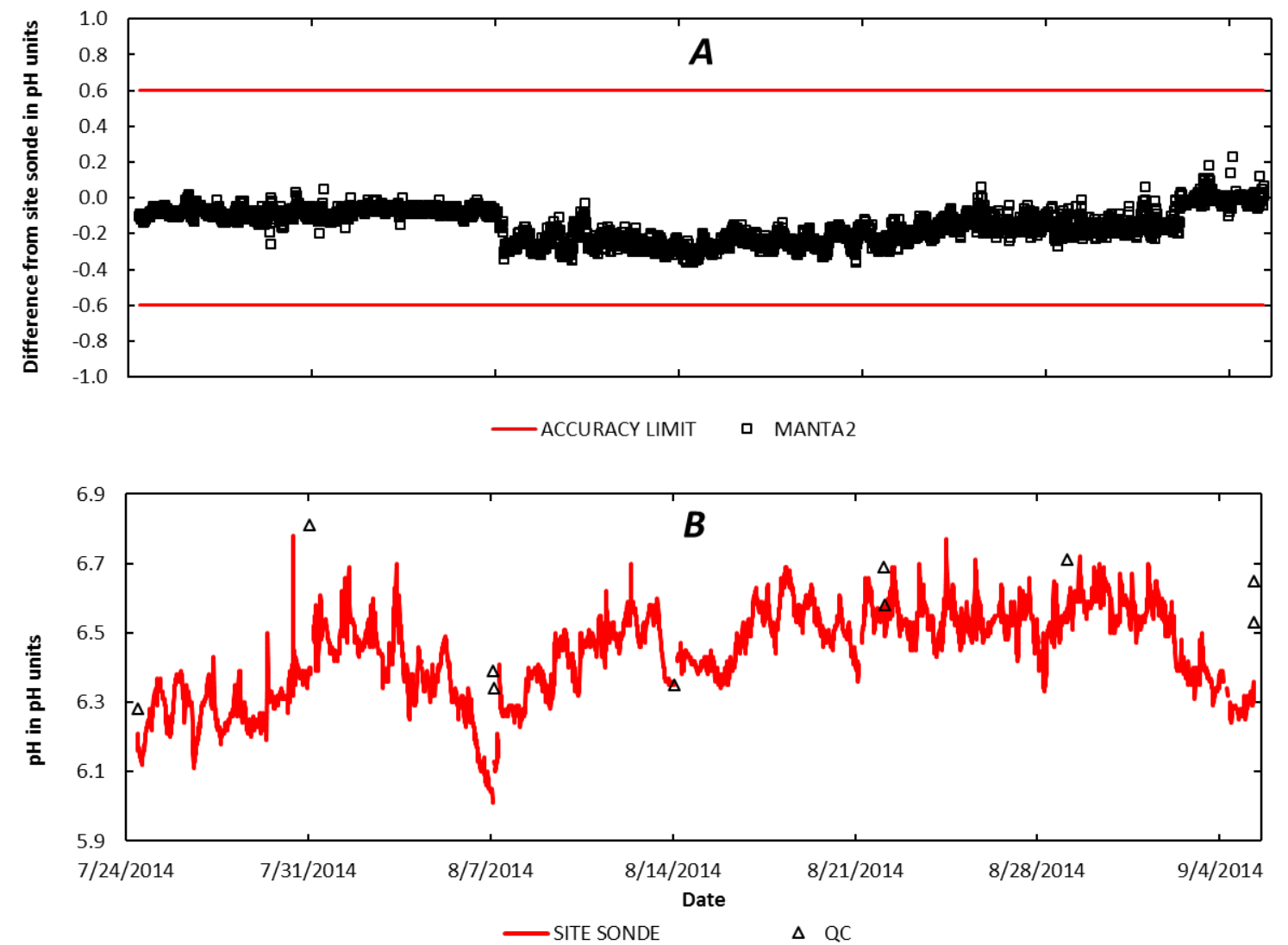

Figure 24. Graphs showing A, pH differences between the Eureka Manta2 3.5 water-quality multiprobe test sonde with biweekly maintenance and the site sonde at U.S. Geological Survey (USGS) station 02492620 (Pearl River at National Space Technology Laboratories Station, Mississippi) over time (6 weeks), and B, pH versus time for the site sonde and a YSI 6920 V2-2 Quality Control (QC) sonde. Differences for the top chart were calculated by subtracting the site sonde's reading from the test sonde's reading. Accuracy limits are twice the limits recommended in table 6.8-5 of chapter 6 of the USGS "National Field Manual for the Collection of Water-Quality Data." 

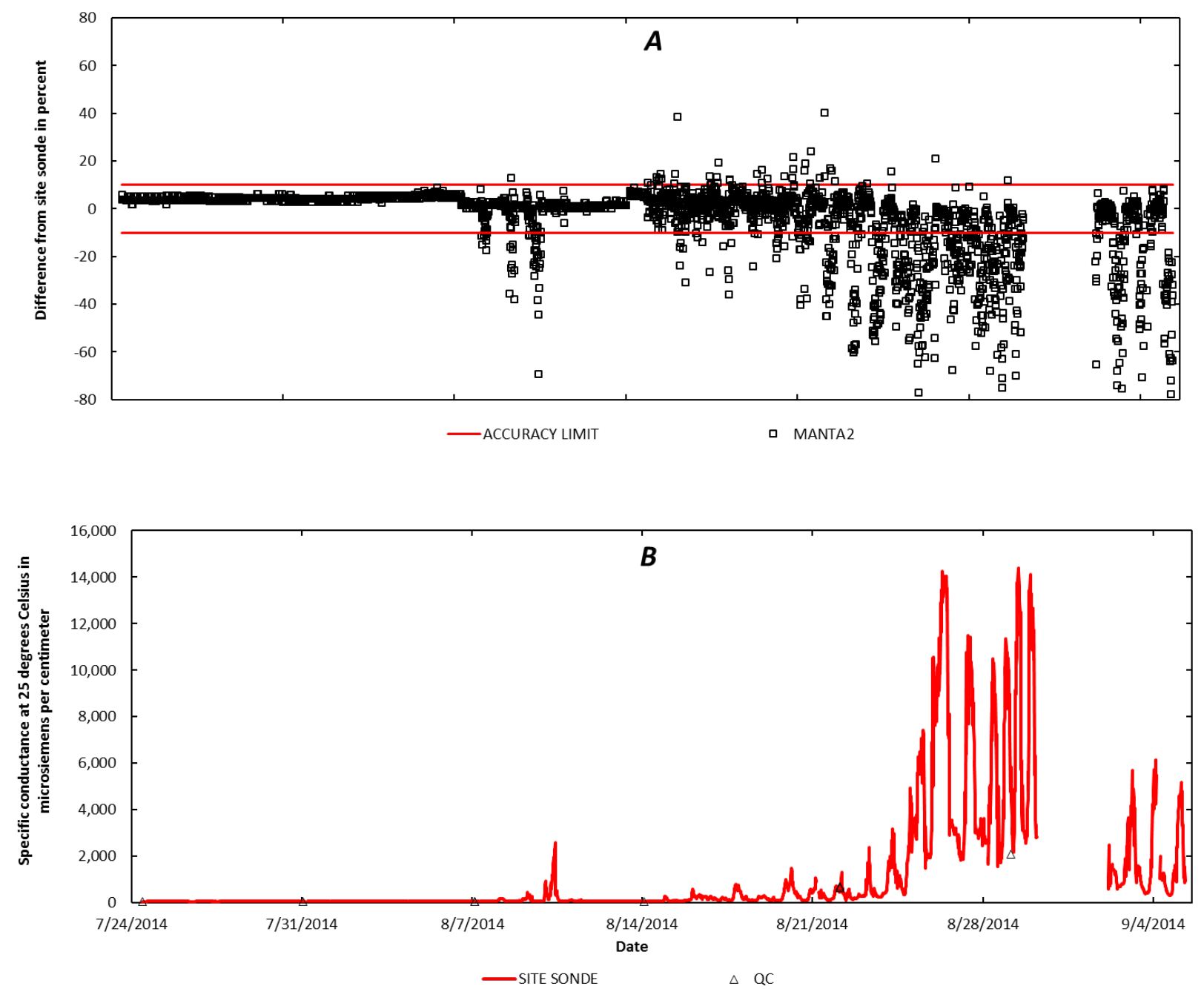

Figure 25. Graphs showing $A$, specific conductance differences between the Eureka Manta2 3.5 waterquality multiprobe test sonde with biweekly maintenance and the site sonde at U.S. Geological Survey (USGS) station (02492620 Pearl River at National Space Technology Laboratories Station, Mississippi) over time (6 weeks), and B, specific conductance versus time for the site sonde and a YSI 6920 V2-2 Quality Control (QC) sonde. Differences for the top chart were calculated by subtracting the site sonde's reading from the test sonde's reading. Accuracy limits are twice the limits recommended in table 6.8-5 of chapter 6 of the USGS "National Field Manual for the Collection of Water-Quality Data." The data gap from August 30, 2014 to September 2, 2014 was caused by the failure of the site sonde's specific conductance sensor. 

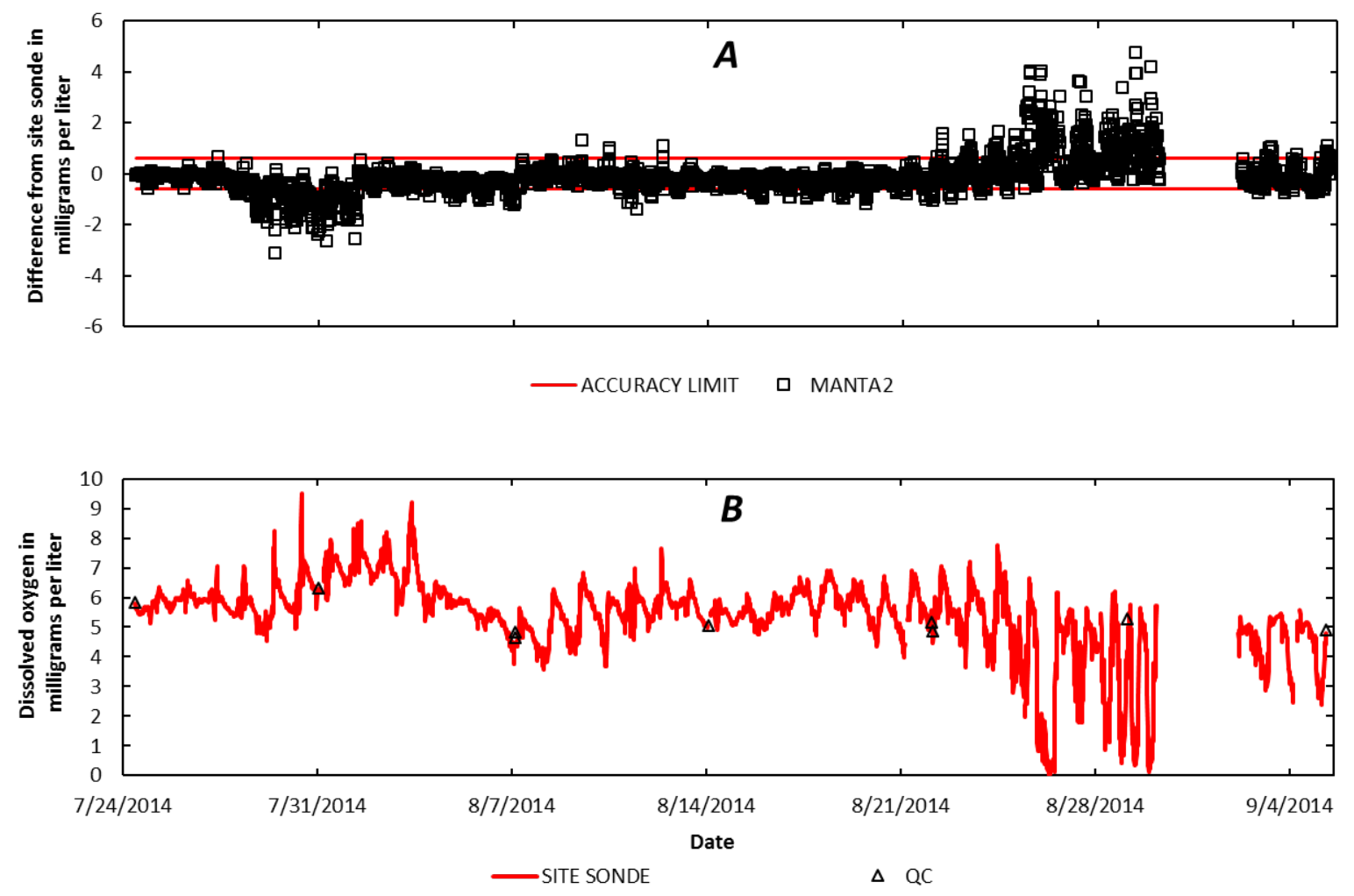

Figure 26. Graphs showing A, dissolved oxygen differences between the Eureka Manta2 3.5 water-quality multiprobe test sonde with biweekly maintenance and the site sonde at U.S. Geological Survey (USGS) station 02492620 (Pearl River at National Space Technology Laboratories Station, Mississippi) over time (6 weeks), and B, dissolved oxygen versus time for the site sonde and a YSI 6920 V2-2 Quality Control (QC) sonde. Differences for the top chart were calculated by subtracting the site sonde's reading from the test sonde's reading. Accuracy limits are twice the limits recommended in table 6.8-5 of chapter 6 of the USGS "National Field Manual for the Collection of Water-Quality Data." The data gap from August 30, 2014 to September 2, 2014 was caused by the failure of the site sonde's specific conductance sensor. 
Table 6. Summary statistics for the test sonde, the Eureka Manta2 3.5 water-quality multiprobe test sonde (serviced biweekly), and the site sonde at U.S. Geological Survey station 02492620 Pearl River at National Space Technology Laboratories Station, Mississippi. (Hydrolab Data Sonde 5 - serviced every week over a 6-week deployment.)

\begin{tabular}{|c|c|c|c|}
\hline Statistic & Site sonde & Test sonde & Difference \\
\hline \multicolumn{4}{|c|}{ Temperature in degrees Celsius } \\
\hline Mean & 29.14 & 29.11 & -0.03 \\
\hline Maximum & 31.8 & 31.65 & -0.15 \\
\hline Minimum & 27.1 & 27.01 & -0.09 \\
\hline Standard deviation & 0.77 & 0.79 & 0.02 \\
\hline Data point count & 4,033 & 4,081 & - \\
\hline \multicolumn{4}{|c|}{$\mathrm{pH}$ in pH units } \\
\hline Mean & 6.44 & 6.29 & -0.15 \\
\hline Maximum & 6.78 & 6.69 & -0.09 \\
\hline Minimum & 6.01 & 5.93 & -0.08 \\
\hline Standard deviation & 0.13 & 0.12 & -0.01 \\
\hline Data point count & 4,033 & 4,081 & - \\
\hline \multicolumn{4}{|c|}{ Specific conductance in microsiemens per centimeter at 25 degrees Celsius } \\
\hline Mean & 1,059 & 944 & -118 \\
\hline Maximum & 14,410 & 13,770 & -640 \\
\hline Minimum & 51 & 53 & 2 \\
\hline Standard deviation & 2,398 & 1,868 & -530 \\
\hline Data point count & 3,753 & 4,081 & - \\
\hline \multicolumn{4}{|c|}{ Dissolved oxygen in milligrams per liter } \\
\hline Mean & 5.40 & 5.20 & -0.2 \\
\hline Maximum & 9.51 & 8.82 & -0.69 \\
\hline Minimum & 0.02 & 0.25 & -0.23 \\
\hline Standard deviation & 1.27 & 1.04 & -0.23 \\
\hline Data point count & 3,753 & 4,081 & - \\
\hline
\end{tabular}

The fouling and calibration drift corrections (table 7) were calculated from the data in accordance with USGS protocol for the correction of field data (table 8) but not applied to the test sonde data. During the site visit on August 7, 2014, the fouling corrections were "Excellent" for $\mathrm{pH}, \mathrm{SC}$, and DO. During the site visit on August 22, 2014, the fouling corrections were Excellent for $\mathrm{pH}$ and SC and Fair for DO. During the final site visit on September 5, 2014, the fouling corrections were Excellent for $\mathrm{pH}$, Poor for SC, and Fair for DO. The test sonde calibration drift ratings computed after each site visit were Excellent, requiring no recalibration during the field test. The Manta2, as tested, had only a wiper for turbidity. Experience at the HIF has shown that automated brushing or wiping of sensors is effective in reducing sensor fouling and minimizing fouling corrections to field data. The DO and turbidity data usually benefit the most from the use of a brush or wiper to reduce fouling. The fouling corrections for DO indicate that the sensor would perform better if used in conjunction with a brush or wiper. A brush or wiper would not work with the SC sensor's design. 
Table 7. Fouling- and calibration-drift corrections for the Eureka Manta2 3.5 water-quality multiprobe test sonde after a 6-week deployment at U.S. Geological Survey station 02492620 Pearl River at National Space Technology Laboratories Station, Mississippi, with maintenance every 2 weeks. The sonde was calibrated on July 22, 2014. The correction values were not applied to the sonde data.

$[\%$, percent $]$

\begin{tabular}{lccc}
\hline \multicolumn{1}{c}{ Correction } & pH & $\begin{array}{r}\text { Specific conductance } \\
\text { at 25 degrees Celsius }\end{array}$ & $\begin{array}{c}\text { Dissolved } \\
\text { oxygen }\end{array}$ \\
\hline & \multicolumn{4}{c}{ Maintenance date 08/07/14 } \\
\hline Fouling & 0.20 & $-6.06 \%$ & $2.24 \%$ \\
Calibration drift & 0.04 & $0.30 \%$ & $0.20 \%$ \\
\hline \multicolumn{4}{c}{ Maintenance date $08 / 22 / 14$} \\
\hline Fouling & 0.19 & $-2.49 \%$ & $17.29 \%$ \\
Calibration drift & 0.09 & $1.28 \%$ & $2.04 \%$ \\
\hline & Maintenance date $09 / 05 / 14$ \\
\hline Fouling & 0.19 & $-16.38 \%$ & $13.74 \%$ \\
Calibration drift & 0.12 & $0.20 \%$ & $1.83 \%$ \\
\hline
\end{tabular}

Table 8. Accuracy ratings of continuous water-quality records, reprinted from U.S. Geological Survey Techniques and Methods 1-D3, table 18, 2006.

$[\leq$, less than or equal to; \pm , plus or minus value shown; >, greater than; $\%$, percent; $\mathrm{mg} / \mathrm{L}$, milligram per liter; $\mathrm{pH}$ unit, standard $\mathrm{pH}$ unit]

\begin{tabular}{llccc}
\hline \multirow{2}{*}{$\begin{array}{c}\text { Measured field } \\
\text { parameter }\end{array}$} & \multicolumn{4}{c}{ Accuracy rating } \\
\cline { 2 - 5 } Excellent & \multicolumn{1}{c}{ Good } & Fair & Poor \\
\hline Specific conductance & $\leq \pm 3 \%$ & $> \pm 3-10 \%$ & $> \pm 10-15 \%$ & $> \pm 15 \%$ \\
at 25 degrees & & & & \\
Celsius & & & & \\
Dissolved oxygen & $\leq \pm 0.3 \mathrm{mg} / \mathrm{L}$ or & $> \pm 0.3-0.5 \mathrm{mg} / \mathrm{L}$ or & $> \pm 0.5-0.8 \mathrm{mg} / \mathrm{L}$ or & $> \pm 0.8 \mathrm{mg} / \mathrm{L}$ or \\
& $\leq \pm 5 \%$, & $> \pm 5-10 \%$, & $> \pm 10-15 \%$, & $> \pm 15 \%$, \\
& whichever is & whichever is & whichever is & whichever is \\
& greater & greater & greater & greater \\
$\mathrm{pH}$ & $\leq \pm 0.2$ units & $> \pm 0.2-0.5$ units & $> \pm 0.5-0.8$ units & $> \pm 0.8$ units \\
\hline
\end{tabular}

\section{Summary}

The Manta2 3.5 water-quality multiprobe sonde was tested at the U.S. Geological Survey (USGS) Hydrologic Instrumentation Facility (HIF) against known standards over the sonde's operating temperature to verify the manufacturer's stated accuracy specifications for $\mathrm{pH}$, specific conductance (SC), dissolved oxygen (DO), and turbidity. The Manta2 was compliant with Serial Digital Interface at 1200 baud (SDI-12) version 1.3. During laboratory testing, the Manta2 met all USGS "National Field Manual for the Collection of Water-Quality Data" (NFM) recommendations and manufacturer's accuracy specification at all $\mathrm{pH}$ values tested, except for $\mathrm{pH} 11.16$ at $15^{\circ} \mathrm{C}$ and $\mathrm{pH} 10.78$ at $40{ }^{\circ} \mathrm{C}$. The Manta2 SC sensors were within the manufacturer's accuracy specifications, except at 100 microsiemens per centimeter $(\mu \mathrm{S} / \mathrm{cm})$ at $15^{\circ} \mathrm{C}, 25^{\circ} \mathrm{C}$, and $40{ }^{\circ} \mathrm{C}$; at $1,000 \mu \mathrm{S} / \mathrm{cm}$ at $40^{\circ} \mathrm{C}$; and at $10,000 \mu \mathrm{S} / \mathrm{cm}$ at $15^{\circ} \mathrm{C}$ and $40{ }^{\circ} \mathrm{C}$. The SC sensors were within the NFM recommendations, except at $100 \mu \mathrm{S} / \mathrm{cm}$ at $40^{\circ} \mathrm{C}$, exceeding the 
test standard value by as much as 25 percent. The Manta 2 water-quality multiprobe met the NFM recommendations and manufacturer's accuracy specifications for DO and turbidity.

A Manta2 sonde was field tested on the Pearl River at USGS station 02492620. During the 6-week field test, the Manta2 showed overall good agreement with the site sonde for temperature, $\mathrm{pH}$, and DO. Differences were observed in SC data, but were most likely due to stratification of the water column and the difference in the deployment depth of the sondes.

\section{References Cited}

Benson, B.B., and Krause, Daniel, Jr., 1980, The concentration and isotopic fractionation of gases dissolved in freshwater in equilibrium with the atmosphere. 1. Oxygen: Limnology and Oceanography, v. 25, no. 4, p. 662-671.

Eaton, A.D., Clesceri, L.S., Rice, E.W., and Greenburg, A.E., eds., 2005, Standard methods for the examination of water and wastewater (21st ed.): American Public Health Association, American Water Works Association, and Water Environment Federation, p. 2-44-2-48 and p. 4-136-4-140.

Eureka Water Probes [2015], Eureka Manta2 water-quality multiprobe sonde user manual: Eureka water probes website, accessed September 7, 2016, at http://www.waterprobes.com/. Gibs, Jacob, Wilde, F.D., and Heckathorn, H.A., 2007, Use of multiparameter instruments for routine field measurements (ver. 1.1): U.S. Geological Survey Techniques of Water-Resources Investigations, book 9, chap. A6, section 6.8, accessed February 3, 2016, at http://water.usgs.gov/owq/FieldManual/Chapter6/6.8_contents.html.

Henry, William, 1803, Experiments on the quantity of gases absorbed by water, at different temperatures, and under different pressures: London, Philosophical Transactions of the Royal Society, no. 93, p. 29-274.

Radtke, D.B., Davis, J.V., and Wilde, F.D., 2005, Specific electrical conductance: U.S. Geological Survey Techniques of Water-Resources Investigations, book 9, chap. A6, section 6.3, accessed February 3, 2016, at http://water.usgs.gov/owq/FieldManual/Chapter6/6.3_contents.html.

Ritz, G.F., and Collins, J.A., 2008, pH (ver. 2.0): U.S. Geological Survey Techniques of WaterResources Investigations, book 9, chap. A6, section 6.4, p. 21, accessed February 3, 2016, at http://water.usgs.gov/owq/FieldManual/Chapter6/6.4_contents.html.

Rounds, S.A., Wilde, F.D., and Ritz, G.F., 2013, Dissolved oxygen (ver. 3.0): U.S. Geological Survey Techniques of Water-Resources Investigations, book 9, chap. A6, sec. 6.2, accessed February 3, 2016, at http://water.usgs.gov/owq/FieldManual/Chapter6/6.2_ver3.pdf.

United Kingdom Accreditation Service, 2007, M3003, The expression of uncertainty and confidence in measurement ( $2 \mathrm{~d}$ ed.): United Kingdom Accreditation Service, p. 11-14.

Wagner, R.J., Boulger, R.W., Jr., Oblinger, C.J., and Smith, B.A., 2006, Guidelines and standard procedures for continuous water-quality monitors - Station operation, record computation, and data reporting: U.S. Geological Survey Techniques and Methods, book 1, chap. D3, p. 13 and p. 24-35; accessed February 3, 2016, at http://pubs.usgs.gov/tm/2006/tm1D3/pdf/TM1D3.pdf. 